DOI 10.4467/25439561KSR.20.009.13298

\author{
Natalia Aleksiejewna Narocznicka
}

Fundacja Historycznej Perspektywy w Moskwie

Europejski Instytut Demokracji i Współpracy w Paryżu

\title{
ROSYJSKA REWOLUCJA I ŚWIAT W XX WIEKU W KONTEKŚCIE „PROBLEMU ROSYJSKIEGO” NA PARYSKIEJ KONFERENCJI POKOJOWEJ ${ }^{1}$
}

\author{
THE RUSSIAN REVOLUTION AND THE WORLD \\ IN THE TWENTIETH CENTURY: \\ VIEWED IN THE CONTEXT OF THE RUSSIAN QUESTION \\ AT THE PARIS PEACE CONFERENCE
}

\section{Streszczenie}

Artykuł systematyzuje kierunki badań związanych ze stuleciem rosyjskiej rewolucji, wojny domowej i zakończeniem pierwszej wojny światowej. Szczególną uwagę poświęca się „rosyjskiemu problemowi” na paryskiej konferencji pokojowej w 1919 roku. Autorka przywołuje mało znane i nowe fakty świadczące o kontrowersjach między państwami ententy w ocenie rewolucji w Rosji, reżimu bolszewickiego, poparcia dla ruchu białych i integralności terytorium Rosji. Zaprezentowana została analiza mało zbadanych aspektów programu Woodrowa Wilsona i tajnej dyplomacji USA, w tym rola amerykańskiej grupy eksperckiej Inquiry, misja Williama Bullitta w Rosji radzieckiej, rozmowy Maksyma Litwinowa i Williama Bucklera, plany uznania władzy bolszewików na zajmowanych przez nich w 1919 roku terytoriach.

${ }^{1}$ Artykuł został za zgodą autorki przełożony z języka rosyjskiego i opublikowany w naszym czasopiśmie. Pierwotna publikacja: Н. Нарочницкая, Русская револючия и мир в XX столетии: через призму "русского вопроса» на Парижской мирной конференции, „Перспективы. Электронный журнал”, 4(12), (октябрь-декабрь) 2017, ss. 7-36. Zamieszczamy przekład ze względu na wagę zinterpretowanych $\mathrm{w}$ artykule dokumentów. 


\begin{abstract}
The author reviews and sums up areas of research focused on the centennial of the Russian Revolution, Civil War and the end of World War One. Special emphasis is put to the Russian question at the 1919 Paris Peace (Versailles) Conference. The article presents both new and little known data revealing the differences among the Allied Powers regarding the Russian Revolution, the Bolshevik regime, support to the White Movement and the integrity of the Russian territory. It also studies some scarcely researched aspects of W. Wilson's program and US secret diplomacy, including the role of the 'Inquiry', the American study group at Versailles Conference; Bullitt's mission to Soviet Russia; negotiations between M. Litvinov and W. Buckler; plans to recognize the Bolsheviks on the territory they were controlling in 1919.
\end{abstract}

Słowa kluczowe: rewolucja rosyjska 1917 r., interwencja ententy, konferencja wersalska, wilsonizm, grupa Inquiry, misja Bullitta, M. Litwinow.

Keywords: Russian Revolution of 1917, Allied intervention, Versailles Conference, "Inquiry" group, Wilsonianism, Bullitt's mission, M. Litvinov

W latach 1918-1919, w kontekście końcowego etapu pierwszej wojny światowej i konferencji wersalskiej, która nakreśliła, już bez Rosji, kruchy nietrwały plan istnienia Europy międzywojennej według planów anglosaskich, rozgrywa się pierwszy etap wojny domowej w Rosji. W tym zawiera się osobliwa symbolika i dramaturgia momentu historycznego dla Rosji, kiedy naród szaleńczo dąży do samounicestwienia, a za kulisami światowej polityki handluje się rosyjskim dziedzictwem.

Znamienne jest, że dokumenty odnoszące się do pozycji USA i Wielkiej Brytanii w stosunku do ogarniętej wojną domową Rosji, z przyczyn oczywistych, przytaczane są wybiórczo przez historiografię radziecką: liczne spośród nich niepodważalnie świadczą nie o dążeniu do obalenia władzy radzieckiej a o wiele większej niechęci do prawosławnego samodzierżawia i obawy przed odrodzeniem się potężnego gracza geopolitycznego, o gotowości wykorzystania klęski swego wiernego sojusznika i wypchnięcia Rosji z pozycji na Morzu Kaspijskim, Morzu Czarnym i w Azji Środkowej, zbudowanej jej dwóchsetletnią obecnością między Zachodem a Wschodem.

Spory na temat przyczyn pierwszej wojny światowej umiejętnie utożsamione z rewolucja, jak nauczał Lew Trocki, Włodzimierz Lenin i Aleksander Parwus, nie milkną do dziś. W klasycznych opracowaniach dominuje jednak uznanie winy Niemiec i państw centralnych.

Podstawowym opracowaniem na temat pierwszej wojny światowej uznawana jest do dziś praca autorytetu francuskiej historiografii Pierre'a Renouvina ${ }^{2}$. Należy podkreślić, że jego sądy na temat odpowiedzialności Niemiec, o decydującej roli

${ }^{2}$ P. Renouvin, Les origines immédiates de la guerre, 28 juin-4 aoüt 1914, Paris, A. Costes, 1925. 
generałów kajzerowskich, którzy uznali za konieczne wykorzystanie stworzonej przez Austro-Węgry sytuacji do rozwiązania niemieckich problemów geopolitycznych, zgodne są $\mathrm{z}$ analizą byłego ministra spraw zagranicznych Imperium Rosyjskiego, Sazonowa. Senior polityki francuskiej, Jean-Pierre Chevènement, nagrodzony w listopadzie 2017 roku na Kremlu Orderem Przyjaźni, w swojej książce o losach Europy pisze:

„Odpowiedzialność za wywołanie wojny całkowicie, jeśli nie wyłącznie, ponoszą liderzy niemieccy. Ten fakt, ustalony już w 1925 roku przez Pierre'a Renouvina, nie został przez nikogo podważony w ciągu całego wieku historycznych poszukiwań”’”.

Pytanie, czy wybuch pierwszej wojny światowej był nieunikniony, jest pytaniem retorycznym. Zbyt wiele znaczących sił było nią zainteresowanych, począwszy od pragnących nowego podziału świata i kolonii do rewolucjonistów, od wszelkich internacjonalistów i wrogów Kościoła chrześcijańskiego do samego Watykanu, snującego intrygi z Anglią przeciw własnej córce duchowej - monarchii habsburskiej. Najmniej wojną zainteresowana była Rosja, która znalazła się w jej krwawym epicentrum, choć i ona miała swój interes i już w trakcie wojny rozmyślała o zdobyczach.

„Z żadnym państwem los nie obszedł się tak surowo jak z Rosją” - powiedział Winston Churchill - ,jej okręt poszedł na dno, kiedy port był na horyzoncie. Burza już minęła, gdy wszystko na nią runęło. Ofiary poniesiono, cała robota skończona [...] Rozpacz i zdrada zapanowały nad władzą, kiedy zadanie wykonano. Długie cofanie zakończyło się [...] bardziej silna, bardziej liczna, o wiele lepiej zaopatrzona armia trzymała długi front [...] Prócz tego żadnych szczególnie trudnych zadań nie trzeba było przedsiębrać; trzeba było pozostawać na posterunku [...] trzeba było utrzymać się; oto wszystko, co odgradzało Rosję od owoców powszechnego zwycięstwa. Dzierżąc zwycięstwo już w swoich rękach, ona upadła na ziemię za życia pożerana przez robactwo"'4.

Do rozpoczęcia prac paryskiej pokojowej (wersalskiej) konferencji Europa leżała w ruinach. Rosja ogarnięta była przez rewolucję. Udostępnione dokumenty i nowe publikacje, także zagraniczne, pozwalają na bardziej dokładną ocenę wpływu krachu historycznej Rosji na geopolitykę całego XX wieku. Szczególnie interesująco pod tym względem przedstawia się historia konferencji wersalskiej, której dylematy można i trzeba rozpatrywać na szerokim tle światopoglądowych wahnięć, zrodzonych w łonie rewolucji bolszewickiej w Rosji, jak również głębokiego kryzysu europejskich insty-

${ }^{3}$ Ж-П. Шевенман, Европа выходит из истории?, Москва, АСТ, 2015, https://www.litmir.me/ $\mathrm{br} / ? \mathrm{~b}=266752 \& \mathrm{p}=1$, [dostęp: 17.01.2021].

${ }^{4}$ W. Churchill, The World Crisis. 1916-1918, New York, Charles Scribner's Sons, 1927, t. 1, ss. 227-229. 
tucji społecznych. Według historyka brytyjskiego Roberta Williama Setona-Watsona pierwsza wojna światowa była:

„Nie tylko najbardziej niszczycielską, ale była rewolucją, przy czym jednocześnie narodowa, polityczną i społeczną, na ogromnych obszarach Europy. Jednym zdaniem, wojna ta była jednocześnie rokiem 1815 i 1848"s.

W końcu XX wieku podobnie ocenił pierwszą wojnę światową rosyjski historyk Anatolij Iwanowicz Utkin. Ta wojna

„zdeterminowała ewolucję świata na resztę czasu. W ciagu czterech lat dokonała się prawdziwa rewolucja w ekonomii, komunikacji, strukturze narodowej, w światowym systemie społecznym. Pierwsza wojna światowa nadała współczesną formę zagadnieniom społecznym".

Konsekwencje postanowień konferencji paryskiej są odczuwalne do dziś, przy czym nie tylko w dziedzinie geopolityki, ale także w sferze ideologii. Tym bardziej niezbędne i pożądane są opracowania retrospektywne i na nowym poziomie naukowym analizujące to kluczowe wydarzenie światowej dyplomacji tamtej epoki.

Opublikowane badania ostatnich dziesięcioleci na temat odrębnych aspektów konferencji wersalskiej i ustalonego w jej ramach porządku, stenogramy rozmów i inne odtajnione dokumenty pozwalają bardziej obiektywnie i dokładnie przedstawić pozycję USA, Wielkiej Brytanii i Francji w związku z problemami, które jednostronnie lub fałszywie oświetlane były w radzieckiej historiografii. To przede wszystkim pokój brzeski i tzw. „interwencja” ententy w opanowanej przez wojnę domową Rosji. W ZSSR dominowała uproszczona, propagandowa teza głosząca, że ententa dążyła do zduszenia władzy radzieckiej, a biali w zamian za jakoby pokaźną (a naprawdę nieznaczną) finansową wojskową pomoc byli gotowi na terytorialne ustępstwa.

Dokumenty i przytoczone w nielicznych nowych publikacjach ${ }^{7}$ dane o rozmowach między Davidem Lloydem George'em, Georges'em Clemenceau i Woodrowem Wilsonem podczas konferencji wersalskiej ujawniają o wiele bardziej złożone i przeciwstawne pozycje sojuszników ententy w stosunku do sytuacji w Rosji. Ich spory i rozbieżności stanowisk w ocenie samej istoty wydarzeń w Rosji ukazują niemożność nie tylko wypracowania wspólnej pozycji przez zwycięzców, ale nawet sformu-

${ }^{5}$ R.W. Seton-Watson, Britain and the Dictators, Cambridge, The Macmillan Company, 1938, s. 52.

${ }^{6}$ А.И. Уткин, Первая мировая война, Москва, Алгоритм, 2001, s. 3.

${ }^{7}$ M. MacMillan, Paris 1919. Six Months That Changed the World, New York, Random House Trade Paperbacks 2012; J.M. Thompson, Russia, Bolshevism and the Versailles Peace, Princeton, Princeton University Press, 2015. 
łowania własnej pozycji, którą mogłyby poprzeć parlamenty, partie i społeczeństwa. Podobnie jak w XXI wieku w Wersalu rolę odgrywały kontrowersje ideologiczne i uwarunkowania wewnątrzpolityczne.

Poważne różnice w podejściu do dramatu Rosji istniały między członkami delegacji brytyjskiej. Minister wojny Winston Churchill publicznie przeciwstawiał się premierowi Lloydowi George'owi, buńczucznie wypowiadając się podczas obrad, a w kuluarach robiąc kolegom uszczypliwe uwagi. Churchill był jedynym, który zdecydowanie wystapił z poparciem zbrojnej walki z bolszewizmem i ostro żądał rzeczywistej interwencji. Na tym tle toczył spór z Lloydem George'em, który, jak ironicznie podkreślił George Curzon w rozmowie z Arthurem Balfourem, sam był trochę bolszewikiem.

Według samego Lloyda George'a, co przytacza znana oksfordzka historyk Margaret MacMillan:

„Postępowi myśliciele w rodzaju jego samego i prezydenta Wilsona uważali uprzedni reżim w Rosji niefunkcjonalnym i tyrańskim, w konsekwencji winnym brutalnej reakcji rewolucjonistów"».

Udziałowi Churchilla w konferencji wersalskiej, jego zadaniom i sporom z Lloydem George'em, poświęcona jest stosunkowo nowa praca wydana na Uniwersytecie w Czelabińsku . Churchill, który przybył na konferencję w celu odbycia rozmów zgodnie $\mathrm{z}$ jego kompetencjami ministra obrony, nieustannie wykraczał za ramy swojego mandatu, co powodowało niezadowolenie szefa brytyjskiej dyplomacji.

Jak dowodzą liczne materiały konferencji wersalskiej, Wilson i Lloyd George, w odróżnieniu od Churchilla, odnosili się wobec bolszewików stosunkowo łagodnie, mając nadzieję, że okrucieństwo i terror prędko ustana, a bolszewizm stopniowo przybierze postać burżuazyjną. Brytyjski premier powoływał się nawet na błędy polityki brytyjskiej podczas rewolucji francuskiej, kiedy Anglia poparła arystokrację francuską na emigracji. Brytyjska delegacja początkowo nie zamierzała zapraszać do Wersalu przedstawicieli białej Rosji - w Londynie już debatowano o rozpadzie Imperium Rosyjskiego. Prezydent USA Wilson zajmował bardziej ugodowe stanowisko, podkreślał, że „samookreślenie narodów” w odniesieniu do Rosji nie oznacza jej podziału, a tylko to, że Rosjanie sami powinni określić swoją przyszłość.

Ogólnie rzecz biorąc sygnatariusze pokoju wersalskiego nie byli zdolni przewidzieć, co stanie się z ogromną Rosją, nie mieli prognozy, dokładnego planu, jak mają w stosunku do niej postapić. Wydarzenia rewolucji rosyjskiej, jak wiadomo, były na

\footnotetext{
${ }^{8}$ M. MacMillan, Paris 1919..., op.cit., s. 68.

9 А.О. Плешко, Роль У. Черчилля в решении «Русского вопроса» на Парижской мирной конференции», „Вестник Челябинского государственного университета” 1915.
} 
Zachodzie przyjmowane niejednoznacznie. Rozpowszechnione tam były różnorodne lewicowe ideologie odrzucające „stary świat”, który jakoby był winien wojny światowej. Amerykańskie środowiska finansowe też reprezentowały pozycję antycarską i nie akceptowały sojuszu z Rosją carską, przeciwstawiając się zawarciu z nią umowy handlowej w pierwszych latach wojny. Rewolucję lutową Stany Zjednoczone przyjęły z entuzjazmem, jako pierwsze uznały Rząd Tymczasowy. Bolszewicka rewolucja październikowa wywołała obawy i dezaprobatę, ale mniejszą niż w stosunku do „carskiego reżimu” i szereg emisariuszy z USA w Rosji otrzymało instrukcję w żadnym wypadku nie przeszkadzać bolszewikom ${ }^{10}$.

Prezydent Wilson po przybyciu na konferencję pokojową do Paryża szokował swoich europejskich partnerów, przepełnionych nudnym religijnym sceptycyzmem, patetyczną deklaracją: „Amerykę spotyka niebywały honor spełnienia swojego przeznaczenia by zbawić świat"11.

Wilson, syn pastora - prezbiterianina, z wiekiem coraz częściej przejawiał religijną egzaltację i nieraz publicznie pytał, co zrobiłby Chrystus, jeśliby teraz był na „naszym miejscu”. Idea „,narodu-odkupiciela” i wczesne polityczne formuły amerykańskiego prowidencjalizmu - doktryna Monroe, idea Manifestu Destiny, doktryna „otwartych drzwi” - przekształciły się w wilsonizm, skupiający liberalną frazeologię postępu, patos kalwińskiego przekonania o własnym boskim powołaniu do zbawienia świata i ustanowieniu „Nowego porządku na wieki” - jak głosi dewiza na pieczęci państwowej USA i banknocie dolarowym.

Nawiasem mówiąc, romantyk Wilson nie był pozbawiony pragmatyzmu i po przyłączeniu się USA do wojny w kwietniu 1917 roku pisał do swojego doradcy, pułkownika Edwarda House'a:

„Kiedy wojna się skończy możemy ich (sojuszników) zmusić, by myśleli po naszemu, bowiem do tego momentu oni, nie mówiąc o wszystkim innym, będą w naszych rękach, jeśli idzie o finanse" $"$.

Jeśli poglądy Wilsona były w niemałym stopniu uwarunkowane jego religijnym światopoglądem i protestancką doktryną millenaryzmu, to poglądy jego alter ego Edwarda House'a były zdecydowanie innego pokroju. To właśnie House miał ogromny wpływ na prezydenta od pierwszych dni ich znajomości na długo przed wersalską epopeją. Ciekawe studium osobowości Wilsona i jego psychicznej zależności od House'a opracował Zygmunt Freud we współautorstwie z przyjacielem

${ }^{10}$ Memorandum by Lieutenant A.A. Berle, Jr., December 10, 1918. Foreign Relations of the United States, 1919. The Paris Peace Conference, vol. II, Washington, GPO, 1942, s. 472.

${ }^{11}$ E.L. Tuveson, Redeemer Nation. The Idea of America's Millennial Role, Chicago, University of Chicago Press, 1980, s. 2.

${ }^{12}$ Cyt. za: Г. Киссинджер, Дипломатия, Москва, Ладомир, 1997, s. 199. 
Williamem Bullittem - tajnym emisariuszem do Rosji radzieckiej, a później dyplomatą i pierwszym ambasadorem USA w ZSRR ${ }^{13}$. Koncepcja House'a-Wilsona zawierała spójną doktrynę ,przebudowy” stosunków międzynarodowych na zasadach demokracji, samostanowienia i wolności, które miały być wypracowane przez jedno centrum - organizację międzynarodową. Podobnie do leninowskiej teorii polityki zagranicznej adresowanej nie do państw a do ludów i grup transgranicznych (proletariacki internacjonalizm), koncepcja Wilsona nie brała także pod uwagę interesu narodowego. Pod koniec pierwszej wojny światowej, która zaszczepiła awersję do wojen i śmierci, egzaltowany Woodrow Wilson rzucił wyzwanie realpolitik.

Także Henry Kissinger, którego bez wątpienia można zaliczyć do „szkoły realizmu" w amerykańskiej filozofii i praktyce polityki zagranicznej ocenia koncepcję Wilsona z pietyzmem:

„Z amerykańskiego punktu widzenia [...] nie brak równowagi sił rodzi destabilizację, a dążenie do jej osiagnięcia [...] światowe bezpieczeństwo nie wymaga obrony interesów narodowych, tylko uznania pokoju jako normy prawnej. Ocena, czy został naruszony pokój winna pozostawać w gestii utworzonego dla tego celu międzynarodowego urzędu, który Wilson określił jako Liga Narodów. W książce H. Kissingera o charakterze naukowym patos pojawia się tylko wtedy, gdy autor charakteryzuje koncepcje mondialistyczne: «Pośród ruin i klęski iluzji w rezultacie krwawej wojny... na arenę międzynarodową wkroczyła Ameryka, przynosząc pewność siebie, moc i idealizm, niewyobrażalne dla jej wyczerpanych europejskich sojuszników»"14.

Watpliwe, że House był idealista, jak również należący do jego kręgu Bernard Baruch, który na pytanie senatorów z amerykańskiej prowincji: „Jak obronimy nasze własne interesy przy zawężeniu wolności na rzecz organizacji międzynarodowej”?, pobłażliwie odpowiedział: „Damy radę, panowie senatorowie”15.

House przywiózł na konferencję wersalską specjalnie wybranych, nie mających doświadczenia dyplomatycznego młodych „ekspertów”, którzy stanowili kręgosłup utworzonej przez niego grupy Inquiry. Właśnie ta drużyna opracowała materiały analityczne, projekty założeń umowy pokojowej i tezy dyskutowane potem przez

13 3. Фрейд, У. Буллит, Томас Вудро Вильсон. 28-й президент США Психологическое исследование, Москва, Прогресс, 1992. Książka wydana w 1967 roku, 30 lat po śmierci drugiej żony Wilsona została poddana krytyce. Jej negatywna ocena była związana z niejednoznacznym stosunkiem do Freuda oraz z tym, że Bullitt, aktywny członek wersalskiej grupy Wilsona-House'a początkowo zachwycał się prezydentem, ale później, obrażony niepowodzeniem swoich propozycji, rozczarował się, a nawet dawał negatywne świadectwo przeciwko impulsywnej działalności Wilsona na forum Kongresu USA.

${ }^{14}$ Г. Киссинджер, Дипломатия, Ладом,, s. 196.

${ }^{15}$ Treaty of Peace with Germany. Hearings before the Committee on foreign relations. United States Senate. $66^{\text {th }}$ Congress, First session, Washington D.C., The GPO, 1919, ss. 1149-1151. 
prezydenta z członkami Rady Dziesięciu ${ }^{16}$. Członkowie grupy Inquiry, do której należeli Bullitt i James Shotwell odbyli tajne misje u czerwonych i białych, aktywnie dyskutowali nad przyszłością Rosji.

Sądząc z opisu debaty wersalskiej, zawartego w stosunkowo niedawnej publikacji Margaret MacMillan, sprawą Rosji zajmowała się głównie delegacja amerykańska, przy czym rozważała możliwość rozwiązania jej w zupełnie innym paradygmacie. Ale nie spotkało się to z aprobatą innych delegacji, które nie dysponowały sprecyzowaną oceną własnych korzyści płynących z danego rozwiązania, ani zapleczem politycznym aprobującym zaangażowanie w sprawy rosyjskie ${ }^{17}$.

Grupa Inquiry o wiele bardziej była zainteresowana nowymi rozwiązaniami w polityce światowej niż zadaniami zwycięzców w stosunku do zwyciężonych. Jej reprezentatywnym przedstawicielem był na przykład J. Shotwell, przekonany propagandysta idei wszechświatowej ponadnarodowej organizacji, który odegrał ważną rolę w utworzeniu Międzynarodowej Organizacji Pracy, opracowaniu koncepcji i statutu Ligi Narodów. Shotwell, który uczestniczył we wszystkich stadiach przygotowawczych konferencji wersalskiej opublikował kalendarz dzienny jej prac: posiedzenia w różnym formacie od grup eksperckich po Radę Dziesięciu, redakcję komunikatów, propozycje tematów, drogę projektów dokumentów - od początkowych szkiców do końcowych wniosków konferencji paryskiej. W tym skrupulatnym dzienniku, jednak dziwnym trafem, brak jest wzmianki o znanych z innych źródeł kontaktach Shotwella z byłym rosyjskim ministrem spraw zagranicznych S. Sazonowem i próbie przygotowania wizyty delegacji białych struktur w USA. O tej jego misji nie wspomina ani jedna książka czy artykuł poświęcony Shotwellowi. Później Shotwell był ekspertem Departamentu Stanu na konferencji ONZ w San Francisco w kwietniu 1945 roku i uczestniczył w przygotowaniu amerykańskich projektów Statutu ONZ, umieszczając w nich poglądy na temat praw człowieka. (Przeciw anglosaskim projektom, które zawierały niebezpieczną ideę „rządu światowego” delegacja radziecka prowadziła wyczerpującą batalię broniąc prawa weta). Przez pewien okres Shotwell stał na czele Fundacji Carnegiego, a w roku 1952 był nawet nominowany do pokojowej nagrody Nobla, w rezultacie przyznanej Albertowi Schweizerowi.

To właśnie grupa Inquiry zrealizowała w toku konferencji paryskiej ukonstytuowanie struktury, która stała się jednym z wpływowych animatorów koncepcji i doktryn amerykańskiej polityki zagranicznej - Rady do Spraw Międzynarodowych (Council on Foreign Relations, CFR), wydającej czasopismo „Foreign Affairs”. CFR

${ }^{16}$ Były to: Włochy, Francja, Japonia, Wielka Brytania i USA. Utworzyły Radę Najwyższą nazywaną również Radą Dziesięciu, zasiadali w niej szefowie rządów i ministrowie spraw zagranicznych. Ponieważ Włochy były słabe, a Japonia mało zainteresowana geopolityką, główną rolę odgrywały trzy pozostałe państwa.

${ }^{17}$ M. MacMillan, Paris $1919 \ldots$,.., op.cit., ss. 68 
była planowana jeszcze w 1916 roku w przełomowym momencie zmiany sytuacji międzynarodowej, a do pomysłodawców tego think tanka należeli związani z kręgiem Warburgów pułkownik Edward House i bankier Paul Warburg ${ }^{18}$. Byłoby pożyteczne usystematyzować i naukowo przeanalizować zróżnicowane doniesienia o różnorodnych mechanizmach i kanałach wpływów niejawnych i jawnych twórców grupy Inquiry na powstanie amerykańskiego sposobu zarządzania światowymi procesami w XX wieku. Takie kwestie na ogół były przedmiotem zainteresowania egzaltowanej publicystyki opisującej je w stylu teorii „spisku światowego”, a wymagają poważnych studiów.

Profesor Charles Seymour napisał w przedmowie do wspomnień pułkownika House o jego niewyobrażalnym wpływie na Wilsona i faktycznym kierowaniu amerykańską polityką zagraniczna. Arthur Houden - zaufany pułkownika twierdził, że:

„We wszystkich sprawach inicjatywa należała do House'a [...] Depertament Stanu USA spadł do funkcji instancji pośredniej służącej realizacji jego idei i archiwum dla depozytu oficjalnej korespondencji. Bardziej konfidencjonalna dyplomatyczna korespondencja przechodziła bezpośrednio przez małe mieszkanie na 35 East-Street. Ambasadorowie krajów walczących między sobą zwracali się do niego, gdy chcieli wpłynąć na decyzje rządu lub zyskać poparcie w pajęczynie transatlantyckiej intrygi" ${ }^{\prime 19}$.

House był jednym z nielicznych, któremu prezydent bezgranicznie ufał i powierzał najbardziej odpowiedzialne zadania, którego Wilson nie krępując się pytał o radę i z kim dzielił się najbardziej tajemnymi planami zagranicznymi.

Zdając sobie sprawę z istotnej różnicy między postępowymi poglądami, które serwowali swojemu egzaltowanemu prezydentowi a spojrzeniem Lloyda George'a, eksperci grupy Inquiry postarali się stworzyć warunki dla zbliżenia geopolitycznych poglądów Ameryki i Wielkiej Brytanii. Właśnie na konferencji wersalskiej zostały zainicjowane działania, żeby Rada do Spraw Międzynarodowych stała się organizacją bratnią w stosunku do tworzonej wówczas brytyjskiej opiniotwórczej elity intelektualnej. Uczestnik tych wydarzeń Arnold Toynbee, który poświęcił londyńskiemu Chatham House 30 lat pracy opisuje, jak w 1919 roku w paryskim hotelu Majestic, w sztabie brytyjskiej delegacji, gdzie zebrali się reprezentanci Stanów Zjednoczonych i Wielkiej Brytanii, zostało utworzone ,prywatne anglo-amerykańskie towarzystwo ds. naukowego zbadania problemów międzynarodowych”. „W rezultacie - dodaje Toynbee - pierwotne anglo-amerykańskie towarzystwo podzieliło się na dwa - Rada

${ }^{18}$ Paul Warburg - kluczowa figura w kręgach finansowych USA, które stworzyły koncepcję przyszłej rezerwy federalnej. Właśnie referat tej grupy zbudowany na ideach Warburga został przedstawiony w 1912 roku Kongresowi USA i stał się podstawą artykułu 251. o rezerwie federalnej.

${ }^{19}$ A.D. Howden, Mr. House of Texas, New York - London, Funk \& Wagnalls, 1940, s. 41. 
Stosunków Międzynarodowych z siedzibą w Nowym Jorku i Królewski Instytut Spraw Międzynarodowych"20.

Znajdujący się w składzie grupy Inquiry i zajmujący się kwestią Rosji Bullitt i James Shotwell współpracowali z innymi rekrutowanymi ekspertami i innymi osobami, które później odgrywały znacząca rolę w polityce amerykańskiej i jej eksperckich oraz dyplomatycznych poczynaniach. Członkami i ekspertami delegacji USA w Wersalu były przyszłe tuzy polityki amerykańskiej czasów zimnej wojny: Allen Dulles - wówczas emisariusz delegacji w krajach bałtyckich ${ }^{21}$ i John Foster Dulles - radca prawny. Walter Lippmann, sekretarz Inquiry, w przyszłości znany publicysta, autor teorii komunikacji, w wieku 29 lat przygotowywał przemówienia Wilsona, redagował znakomite wystapienie prezydenta na temat programu „Czternaście punktów”, uczestniczył w napisaniu projektu paktu o Lidze Narodów. Do tej grupy należał także Isaiah Bowman, później wiceprezydent Rady Stosunków Międzynarodowych, kierował też Uniwersytetem Johnsa Hopkinsa. Jak utrzymywał J. Shotwell jako świadek, uczestnik i badacz paryskiej konferencji pokojowej:

„Retrospektywny ogląd prac przygotowawczych grupy Inquiry ujawnia, że zagadnienia opracowywane przez delegację amerykańską i jej wpływ na konferencję pokojową miały znaczenie fundamentalne, ponieważ od niej w dużej mierze zależał nie tylko przebieg samej konferencji, ale także warunki umów"²2.

W anglo-amerykańskiej historiografii konferencji wersalskiej Rosji nie poświęca się wiele uwagi. Także popularnonaukowa książka o pierwszej wojnie światowej Normana Stone'a i doskonale udokumentowana obszerna praca Margaret MacMillan ${ }^{23}$ zawierają zaledwie nieduże rozdziały poświęcone problematyce rosyjskiej, zagubione w masie innych tematów i aspektów konferencji. Wyjątkiem było pojawienie się opracowania Russia, Bolshevism and the Versailles Peace amerykańskiego historyka Johna M. Thompsona ${ }^{24}$ specjalizującego się w historii Rosji. Historycy stosunków międzynarodowych ignorują tę problematykę.

Norman Stone, sympatyk Turcji, nieprzypadkowo wyjechał do pracy na Uniwersytecie w Ankarze. Porzuciwszy brytyjskie intelektualne środowisko prawdopodobnie znalazł się poza horyzontem tamtejszych poglądów geopolitycznych, które

${ }^{20}$ А.Дж. Тойнби, Цивилизащия перед судом истории. Сборник, пер. И.Е. Киселевой, М.Ф. Носовой, Москва, Прогресс-Культура, Ювента, 1996, ss. 238-239.

${ }^{21}$ Memorandum by A.W. Dulles. 30 December 1918. Foreign Relations of the United States, 1919. The Paris Peace Conference, vol. II. Washington D.C., The GPO, ss. 481-482.

${ }^{22}$ J.T. Shotwell, At the Paris Peace Conference, Appendix VII. The Organization of the American Delegation, Macmillan Company, New York 1937.

${ }^{23}$ Н. Стоун, Первая мировая война: Краткая история, пер. с англ. И.В. Лобанова, Москва 2010; M. MacMillan, Paris 1919..., op.cit.

${ }^{24}$ J.M. Thompson, Russia, Bolshevism and the Versailles Peace, op.cit. 
w sytuacji najmniejszego kryzysu w Rosji, charakteryzował niezupełnie uświadomiony arogancki stosunek wobec jej interesów wraz z wykreśleniem $\mathrm{z}$ horyzontu wpływów.

Stone rozpoczyna swoją książkę nie inaczej, jak „,pięknym” obrazem podpisania pokoju brzeskiego, demonstrując tym samym, co faktycznie zadecydowało, jego zdaniem, o nowym porządku w Europie i było rezultatem pierwszej wojny światowej. Czysto intelektualne konstrukcje sąsiadują z całkiem trafnymi uwagami na temat krachu ZSRR.

„Trudno sobie wyobrazić bardziej surrealistyczne rozmowy międzynarodowe na temat pokoju - pisze Stone. Z jednej strony za stołem siedziała delegacja Niemiec i ich sojusznicy: europejscy arystokraci w smokingach, rozparci w fotelach z pogardliwo-pobłażliwymi minami, zięć imperatora Austrii książę Leopold Bawarski w mundurze feldmarszałka, turecki pasza i bułgarski pułkownik. Druga delegacja reprezentowała nowe państwo, wkrótce nazwane Rosyjską Radziecką Federalną Socjalistyczną Republiką. Kto ją reprezentował? Żydzi-intelektualiści. Madam Bicenko niedawno zwolniona z więzienia, gdzie siedziała za zabójstwo generał-gubernatora. «Delegat chłopów» zwerbowany naprędce na ulicy rosyjskiej stolicy ,jako eksponat” (przeważnie był pijany). Admirał i kilku oficerów sztabowych, spuścizna po starym reżimie, którzy wiedzieli jak kończyć wojnę i wyprowadzać wojska $\mathrm{z}$ frontu (jeden $\mathrm{z}$ nich posiadał poczucie humoru i prowadził dziennik). Wszyscy oni z zadowoleniem pozowali przed obiektywem. W końcu nastał pokój. [...] Wojna unicestwiła carską Rosję. Bolszewicy w październiku 1917 roku zdobyli władzę; obiecali pokój narodom. Teraz w Brześciu Litewskim podpisali go pod dyktando Niemiec" 25 .

Warunki umowy pokojowej były sformułowane bardzo przemyślnie. Niemcy nie żądały dla siebie dużych terytoriów. Rosja zobowiązywała się tylko „oczyścić” ziemie zachodnie i Kaukaz, żeby zamieszkujące je narody mogły uzyskać niepodległość. W rezultacie geograficzne granice stały się zaskakująco podobne do granic dzisiejszych: wątpliwą samodzielność otrzymały państwa bałtyckie (włączając Finlandię) i Kaukaz.

Największym państwem rozpostartym między centralną Europą a Wołgą okazała się Ukraina. Jej odłączenie się od Rosji oznaczało dla Imperium Rosyjskiego utratę czterdziestu milionów mieszkańców i trzech czwartych wydobycia rud żelaza i węgla kamiennego. $Z$ jej przedstawicielami (niedouczonymi studentami w pomiętych ubraniach i bankierami-oportunistami, ludźmi gotowymi, jak pisał Flaubert, zapłacić za to, żeby ich kupiono) Niemcy podpisali 9 lutego osobną umowę. Z bolszewikami umowa była podpisana później, 3 marca”. Dalej Stone pisze: „Z Ukrainą Rosja -

${ }^{25}$ Н. Стоун, Первая мировая война.., ор.cit., ss. 3-4. 
Stany Zjednoczone, bez Ukrainy Rosja - Kanada, mniej słońca, więcej śniegu”. Podobnie wypowiedział się w 1991 roku Zbigniew Brzeziński.

„Po pokoju w Brześciu Litewskim pojawiły się ponownie te państwa, co po rozpadzie Związku Radzieckiego. W 1918 roku one były satelitami Niemiec. [...] Wtedy Niemcy dążyły do tego, by stać się imperium światowym; teraz, znajdując się w sojuszu z Zachodem, nie dążą do takiego celu. [...] Dzisiaj wszyscy chcą mówić po angielsku, nie po niemiecku jak w 1918 roku. Współczesna Europa jest Europą czasów pokoju w Brześciu Litewskim, ale z ,ludzką twarzą”. Dla uzyskania go potrzebna była druga wojna światowa i anglo-amerykańska okupacja Niemiec"26.

Siergiej Sazonow rozumiał, co oznacza uznany kiedyś przez władze rosyjskie rozpad państwa. Mówiąc: „Czym zaowocowało dla narodu rosyjskiego narzucone mu przez międzynarodówkę zrzeczenie się dziedzictwa historii, stanie się jasne dopiero przyszłym pokoleniom" ${ }^{27}$ - przewidział niejako paradę wolności lat 90. zapoczątkowaną w 1918 roku.

Tak więc, według Stone'a, nie zważając na krótkotrwały sukces w Brześciu Litewskim, Niemcy poniosły klęskę, a nowy wiek stał się wiekiem anglosaskim. Wszystko to, czego nie udało się dokonać Teutonom z powodzeniem wykorzystali Anglosasi.

Margaret MacMillan przy całej naukowej skrupulatności i braku uprzedzeń reprezentuje czysto brytyjskie stanowisko całkowicie dopuszczające i nawet przewidujące świat bez Rosji. Rozpoczyna od uwagi o tym, że francuski premier Georges Clemenceau, który nalegał podczas otwarcia konferencji wersalskiej na koronację Wilhelma I na cesarza „nowych Niemiec”, nawet nie użył jakże nieprzyjemnego dla Wielkiej Brytanii terminu „Imperium Niemieckie”.

MacMillan akcentuje nieporozumienia między Francją i Niemcami, ale nie między Niemcami a Wielką Brytanią. Wyodrębnia te dokumenty i wypowiedzi twórców traktatu wersalskiego, w których daje się zauważyć stosunek do Rosji niczym do uciążliwego bólu głowy, choć podkreśla, że Francja uratowana została przez Rosję od klęski, niosącej główne ciężary wojny. Jednak dla zwycięzców byłoby o wiele bardziej honorowo nie wtrącać się, zamknąć Rosjan w zamkniętej przestrzeni, „za drutem kolczastym", żeby doczekać się wyniku, kiedy oni skończą się bić, a tym czasem bez Rosji postanowić o jej granicach, kiedy już nie będzie Rosją. Ale na przeszkodzie stali nie bolszewicy a organizacje białych. A historia stosunku ententy do swojej sojuszniczki Rosji - to historia naprzemiennej i jednoczesnej gry z czerwonymi i białymi, która skończyła się zdradą ententy w stosunku do białych.

\footnotetext{
${ }^{26}$ Н. Стоун, Первая мировая война..., ор.cit., s. 4.

${ }^{27}$ С.Д. Сазонов, Воспоминания. Репринтное воспроизведение издания 1927 года, Париж - Москва, Международные отношения, 1991.
} 
Przedstawiciela białych na konferencję nie zaproszono, chociaż do Paryża zjechali przedstawiciele mnóstwa najrozmaitszych antybolszewickich organizacji w nadziei na udział w konferencji.

Nota bene świetnie udokumentowany fundamentalny artykuł Siergieja Wiktorowicza Listikowa ${ }^{28}$ ukazuje stan pełnego chaosu w tym eklektycznym środowisku, a nawet męczącą rywalizację przybyłych do Paryża rosyjskich działaczy, począwszy od byłych posłów i ministrów carskiej Rosji: Wasilija Makłakowa, Michaiła Girsa, Władimira Kokowcewa, Aleksnadra Izwolskiego, Siergieja Sazonowa do członków Rządu Tymczasowego: Aleksandra Kiereńskiego, Gieorgija Lwowa, Nikołaja Aksjentjewa, Michaiła Rodzianko, Pawła Milukowa, Nikołaja Czajkowskiego i Borysa Sawinkowa, którego w odróżnieniu od carskich dyplomatów francuska lewica przywitała z entuzjazmem. Biali liczyli na to, że już samo uznanie pokoju brzeskiego i wierność entencie spowoduje, że zachodni sojusznicy włączą białą Rosję do swojego wersalskiego gremium, sami zaś byli niezdolni do zaniechania wewnętrznych ideowych sporów, by uniemożliwić wyłączenie Rosji z systemu stosunków międzynarodowych. $Z$ trudem odnajdywali wspólny język przedstawiciele archangielskiego, omskiego i południowego „rządu” posiadający własne organizacje wojskowe. Dziesiątki innych niezwiązanych $\mathrm{z}$ armiami białych działaczy nie zaprzestawały walki politycznej, jaką rozpoczęli jeszcze przed rewolucja lutową.

Po długich utyskiwaniach emigracji rosyjskiej na temat niepowodzeń białych i oczerniania przed zachodnimi demokracjami władzy radzieckiej trudno uwierzyć, że ugrupowania niebolszewickie, szukając poparcia ententy i społeczeństwa europejskiego, zmuszone były zademonstrować (nieszczerze, a liczni gorliwie i szczerze) bardziej lewicowe przekonania niż ich przeciwnicy. Kiereński i szereg byłych działaczy Rządu Tymczasowego skierowali nawet notę do Woodrowa Wilsona z prośbą, żeby ten nie uznawał „dyktatora” Kołaczaka i nie spotykał się z carskim ministrem - „reakcjonistą” Sazonowem. Przybycie Sazonowa z Londynu spotkało się z wrzawą w prasie francuskiej i zajadły republikanin, premier Clemenceau odmówił przyjęcia ministra spraw zagranicznych Imperium Rosyjskiego, które na początku wojny uratowało Francję od nieuniknionej klęski, co potwierdził marszałek Foch.

Jeśli w pewnym momencie Georges Clemenceau i Vittorio Orlando nieustannie mówili, że biali powinni prędko się zjednoczyć, żeby można było im pomóc, to Lloyd George wolał wykorzystać nieokreśloność amorficznego, rozdartego kłótniami „rosyjskiego rządu”. W modzie była lewica i Rosja była skazana. Wszelkie rozmowy z licznymi rosyjskimi emisariuszami od Denikina, od „rządu” w Omsku, od zdymisjonowanego Rządu Tymczasowego i z innymi ograniczyły się do kontaktów formalnych.

${ }^{28}$ С.В. Листиков, Мир без России: представительство Белого движения на Парижской конференции, „Вестник МГИМО” nr 1(4), 2009, ss. 15-30. 
Siergiej Listikow, który studiował skomplikowane stosunki między działaczami antybolszewickimi i delegacjami zwycięzców na konferencji paryskiej, dowodzi, że „Wzmożony kierunek probolszewicki” w polityce szeregu wiodących działaczy państw zachodnich był jawny. Stawał się on tą ważną „cegiełką”, która umocniła rosnący mur obcości między rosyjską dyplomacją, politykami w Paryżu i Omsku oraz ich zachodnimi partnerami. Ci pierwsi nie przestawali uważać się za przedstawicieli ogromnego państwa, chwilowo pozbawionego mocy i wpływów na sprawy międzynarodowe, z trudem znosili upokorzenia i obrazę narodowej godności, które odczuwali podczas zakulisowych intryg zwycięskich demokracji i nader szybkiego zapomnienia przez nie zasług Rosji podczas krwawej wojny ${ }^{29}$.

Choć liderzy Rosyjskiej Rady Politycznej stopniowo pogodzili się z koniecznością przyjęcia spornych warunków zaproszenia ich na konferencję, to perspektywa udziału w niej prędko się rozwiała. Tymczasem delegacja amerykańska, grupa Inquiry i sam Wilson coraz bardziej przychylni byli kontaktom z bolszewikami. „Nowe nastroje" amerykańskiej drużyny intelektualnej Inquiry znalazły swój wyraz podczas konferencji wersalskiej nie tylko w idei ponadnarodowego organu mającego służyć rozwiązywaniu międzynarodowych sporów, ale także „problemu rosyjskiego".

Rolę pośrednika między Wersalem i władzą rewolucyjną w Rosji spełniał młody członek grupy Inquiry William Christian Bullitt posłany do Moskwy, żeby wyjaśnić, na jakie ustępstwa są skłonni pójść bolszewicy, dla zachowania „cytadeli rewolucji”. Został przyjęty przez Lenina i był nim oczarowany, polubił czarny kawior, uwierzył w perspektywy polityki bolszewików i pożytek z ich uznania. Razem z amerykańskim dyplomatą w Rosji Williamem Bucklerem Bullitt prowadził główne, określające istotę jego „poselstwa”, rozmowy z Maksymem Litwinowem, który potem telegrafował propozycje bolszewików do Paryża.

William Bullitt i towarzyszący mu publicysta Lincoln Steffens, którzy odwiedzili bolszewicką Rosję z poręczenia głównego architekta gabinetu Wilsona, Edwarda House'a, reprezentowali zdecydowanie lewicowe poglądy. Wyróżniającym się przedstawicielem lewicowej filozofii w dziedzinie „transformacji” polityki światowej był także James Thomson Shotwell, był on nie tylko ekspertem-praktykiem, ale $i$ autorem prac teoretycznych i historycznych. $Z$ jego osobą związane jest sformułowanie w środowisku politycznie zaangażowanych historyków amerykańskich koncepcji udziału USA w jednolitym globalnym systemie, w którym Ameryka powinna była odgrywać czołową rolę, odżegnując się od tradycyjnego izolacjonizmu jako nieodpowiadającego nowemu etapowi historii ${ }^{30}$. W 1919 roku - równolegle z misją Bullitta do rewolucyjnej Rosji - House wysłał Shotwella do Sazonowa, który pełnił

\footnotetext{
${ }^{29}$ Ibidem, s. 21.

${ }^{30}$ H. Josephson, James T. Shotwell and the Rise of Internationalism in America, Madison, NJ: Fairleigh Dickinson University Press, 1974.
} 
rolę dyplomatycznego przedstawiciela białych, przede wszystkim Sił Zbrojnych Południa Rosji - Antona Iwanowicza Denikina.

Badanie tych misji pomaga prześledzić historię filozoficznych podstaw amerykańskiej roli w kierowaniu światem, poszerza rozumienie ideowych i geopolitycznych następstw rewolucji 1917 roku, pozwala ujawnić związek między wydarzeniami stuletniej przeszłości i naszych czasów. Rewolucja rosyjska i rozpad starej Europy stworzyły warunki dla pierwszego zastosowania koncepcji Wilsona. Krach ZSRR i powstała na początku XXI wieku europejska konfiguracja z prawie postwersalskim skrzydłem niesamodzielnych państw od Bałtyku do Morza Śródziemnego znowu stworzyły możliwości (i pokusę) budowy „nowego świata” według amerykańskiego szablonu.

Po stu latach koncepcja Wilsona znajduje swoje odzwierciedlenie w o wiele mniej patetycznej formie. Zgłaszając pretensje do ,wyjątkowości” i przybierając postać trockistowskiej idei światowej liberalnej rewolucji, coraz bardziej przybiera ona charakter prymitywnego imperializmu Teodora Roosevelta, z jego przekonaniem, że USA maja prawo do wojen zaborczych i są przez Boga wyznaczeni do „kierowania dzikusami i złymi narodami”, według słów znanego ideologa tej polityki - senatora Alberta Beveridge'a.

Mało zbadane i naukowo nieprzeanalizowane są nie tylko różne aspekty misji Bullitta do rewolucyjnej Moskwy, ale także jego dalsze działania w „kwestii rosyjskiej”. Cały projekt House'a, jego różnorodne związki z wpływowymi zakulisowymi autorami nowej amerykańskiej globalnej strategii do dziś pozostają niewyjaśnione na Zachodzie i nieuświadomione w pełnym wymiarze w Rosji. Poza tym w zachodnich archiwach, na przykład na Uniwersytecie w Yale, dostępne są dokumenty, a opublikowane książki częściowo rzucają światło na rozmowy, które Bullitt prowadził w 1919 roku w Moskwie ${ }^{31}$.

Obecnie wzrost zainteresowania tym ważnym epizodem nastąpił w związku z pojawieniem się po upadku ZSRR, jak to określił N. Stone - „brzeskich” państw. Zaczęła krążyć beletrystyczna opowieść o „bon vivancie” Williamie Bullittcie pierwszym ambasadorze USA w ZSRR - ,romansującym z baletnicami Wielkiego Teatru", urządzającym fantastyczne przyjęcia w Spaso House, opisane jako bal u Szatana w powieści Michaiła Bułhakowa Mistrz i Małgorzata ${ }^{32}$. Według relacji Aleksandra Etkinda ten pełen obyczajowych szczegółów literacki opis oparty jest częściowo

${ }^{31}$ B. Farnsworth, William C. Bullitt and the Soviet Union, Bloomington, Indiana University Press, 1967; M. Casella-Blackburn, The Donkey, the Carrot, and the Club: William C. Bullitt and Soviet-American Relations, 1917-1948, Praeger, Westport, Conn 2004; W. Brownell, R. Billings, So Close to Greatness: The Biography of William C. Bullitt, New York, Macmillan, 1988.

32 Zob. А. Эткинд, Мир мог быть другим. Уильям Буллит в попытках изменить ХХ век, Москва, Время, 2015. 
na zawartości archiwum Bullitta z Uniwersytetu w Yale, ale bez zaznajomienia się z rosyjskimi archiwami. Autorce tego artykułu nie udało się otrzymać w Archiwum Polityki Zagranicznej Rosyjskiej Federacji (2000 r.) dokumentów, notatek o rozmowach Bullitta z Leninem i Litwinowem (możliwe, że uda się to następnym badaczom). Udało się natomiast dotrzeć do pełnego sprawozdania Bullitta dla Senatu sporządzonego w związku z rozpatrywaniem przez Kongres USA umowy wersalskiej i paktu o Lidze Narodów, który został odrzucony przez konserwatywnych senatorów z amerykańskiej prowincji, którzy nie rozumieli romantycznych wizji Wilsona i pragmatycznych kalkulacji jego alter ego, E. House'a, na temat nowej roli Stanów Zjednoczonych.

W jednym z dokumentów zaprezentowanych przez Bullitta (Bullitt Exhibit N11) znajduje się zapis rozmowy Lloyda George'a i Wilsona w gabinecie francuskiego ministra spraw zagranicznych Stephena Pichona na Quai d'Orsay, który rzuca światło na stosunek Wilsona do tzw. „interpretacji”. Wilson powiedział, że: „Amerykańskie wojska nie są gotowe do wkroczenia do Rosji i pokonania bolszewików” i thumaczy się to brakiem przekonania o tym, że: „W przypadku zwycięstwa nad bolszewizmem nie nastąpi restauracja starego porządku"33.

Program „Czternastu punktów”, w świetle którego, jak oczekiwał romantyk Wilson, powinna była zblednąć ideologia imperialna Starego Świata był odczytany w Archiwach pułkownika House'a jako „realna polityka”: „Rosja jest zbyt duża i jednorodna, trzeba ją zredukować do rozmiarów Wyżyny Środkoworosyjskiej. [...] Przed nami powstanie czysta karta, na której nakreślimy przyszłe losy rosyjskich narodów”. Punkt szósty przewidywał na terytorium Imperium Rosyjskiego ,uznanie istniejących już rządów” i ,pomoc dla nich”. Mowa była o Radzie Ukraińskiej, okupowanych przez wojska kajzerowskie Estonii, Łotwie, Litwie, a także o czerwonych i białych na zajmowanych przez nie terenach i o wyprowadzeniu z proklamowanych państw wszystkich obcych wojsk ${ }^{34}$.

Pod pojęciem obcych wojsk na ,uznawanych faktycznie istniejących terytoriach" rozumiano obie Armie - Białą i Czerwoną, które dążyły do odzyskania jedności terytorialnej państwa, a także wojska japońskie znajdujące się w Mandżurii w celu zajęcia Zabajkala, co zdecydowanie nie leżało w interesach USA. Na uwadze miano także wojska ententy - a dokładnie brytyjskie, które mogłyby utworzyć region kontrolowany przez Wielką Brytanię, co także nie odpowiadało „nowym poglądom” House'a i Wilsona. W istocie wszystko to oznaczało międzynarodową zgodę i zatwierdzenie rozpadu historycznej Rosji.

${ }^{33}$ Treaty of Peace with Germany. Hearings before the Committee of foreign relations. United States Senate. $66^{\text {th }}$ Congress, First session, The GPO, Washington D.C., 1919, s. 1238.

${ }^{34}$ Zob. Ch. Seymour (ed.), The Intimate Papers of Colonel House, vol. IV, London, Ernest Benn, 1928, ss. 202-204. 
W radzieckiej historiografii za główny cel i istotę polityki zachodnich państw w stosunku do porewolucyjnej Rosji uznano walkę klasową z władzą radziecką. Jednak podstawową treścią polityki światowej są nieustannie realne ideowe i geopolityczne dążenia państw, dziedziczne fobie i uprzedzenia, walka wokół strategicznego dostępu do mórz i magistralnych stref. Wszystko to znalazło odzwierciedlenie w stosunku do Rosji i ZSRR podczas ważniejszych momentów historii i poważnych zwrotów w sytuacji międzynarodowej. W przełomowych momentach dziejów Rosji miały miejsce skomplikowane geopolityczne scenariusze. Tak było w latach 19171919, w czasie obu wojen światowych, w momencie rozpadu ZSRR i po nim.

Pułkownik House jeszcze podczas rewolucji lutowej uprzedził prezydenta Wilsona, że:

„Nic nie należy robić ponad zapewnienie Rosji o naszym poparciu dla jej prób zaprowadzenia trwałej demokracji i gotowości udzielenia wszelkiej możliwej pomocy finansowej, przemysłowej i moralnej" ${ }^{35}$.

To zdecydowanie różniło się od pozycji Churchilla, który przesłał wyrazy współczucia i szacunku w związku z rosyjska tragedią. Sir Winston Churchill książę Marlboro był zdystansowany wobec tych sił na Zachodzie, które żywiły się ideą rewolucji.

„Ja nie uznaję prawa bolszewików na reprezentowanie Rosji. [...] - mówił w Izbie Reprezentantów 5 listopada 1919 roku - Bolszewicy jednym uderzeniem ukradli Rosji dwa jej najcenniejsze skarby: pokój i zwycięstwo..." ${ }^{\text {36 }}$.

Jednak Edward House należał do tych kręgów kosmopolitycznych wyznających pretensje uniwersalistyczne, dla których rewolucja i pierwsza wojna światowa kupiła tradycyjne społeczeństwa chrześcijańskie, które zaczęły sprzyjać dowolnemu systemowi bardziej niż „carskiemu reżimowi”. Wilson też był postronnym obserwatorem dramatu starego kontynentu - psychologicznie i emocjonalnie nie był przywiązany do tego porządku, który zburzyła wojna i bolszewizm. I choć wyjście Rosji radzieckiej z wojny, jej separatystyczny pokój z Niemcami zmieniały pozycję ententy, dla USA nie odgrywało to istotnej roli.

Dokumenty odnoszące się do pozycji USA i Wielkiej Brytanii w stosunku do ogarniętej wojną domową Rosji w historiografii radzieckiej wykorzystywane były wybiórczo. Pomijano to, co jednoznacznie świadczyło o tym, że głównym celem nie było pokonanie władzy radzieckiej. Niepożądana była restauracja samodzierżawia

\footnotetext{
${ }^{35}$ Ibidem, s. 204.
}

${ }^{36}$ W.S. Churchill, His Complete Speeches, 1897-1963, vol. 2, ed. R.R. Games, New York, Chelsea House Publishers; R.R. Bowker Company, 1974, Speech in the House of Commons 5.11.1919. 
i jedności terytorialnej Imperium Rosyjskiego. Sojusznicy z ententy, przede wszystkim USA, prowadzili zakulisową grę z bolszewikami $\mathrm{i}$ ani trochę nie popierali jednoznacznie białych, nie kierując się żadnymi zasadami współpracowali z Armią Czerwoną przeciw Białej.

Polityczne motywacje państw zachodnich, na których skupiała uwagę historiografia radziecka, niewatpliwie zaciemniały prawdę o ich stosunku do czerwonych bądź białych. Zapobieżenie rozprzestrzenieniu bolszewizmu na inne państwa, które były na granicy rewolucji też nie budzi wątpliwości. Ale główne pobudki miały geopolityczny i wojskowo-strategiczny charakter. Tak zwana interwencja ententy w Rosji służyła realizacji wschodnioeuropejskiego szkicu i powstrzymywaniu Japonii na Dalekim Wschodzie, a nie zadaniu zwyciężenia bolszewizmu czy pomocy białym w odbudowie Rosji. Wzajemne stosunki białych i ententy były bardzo skomplikowane i powodowały nieustanne rozczarowanie tych pierwszych, co opisał Denikin w Szkicach smuty rosyjskiej i Sazonow w swoich pamiętnikach, które zawierały zapiski Gieorgija Michajłowskiego, przebywającego wówczas w Paryżu w charakterze pośrednika między Denikinem i Sazonowem. To nie dziwi, ponieważ wszystkie białe rządy twardo optowały za zachowaniem całości Rosji i nie szły w tym względzie na żadne kompromisy, nawet w zamian za pomoc Zachodu. Bolszewicy zaś, jak wyjaśnił Bullitt, byli gotowi zgodzić się na rozpad Rosji. Notatki z posiedzeń Rady Dziesięciu, która składała się z szefów rządów i ministrów spraw zagranicznych: USA, Wielkiej Brytanii, Francji Włoch i Japonii oraz Wielkiej Czwórki (czołowych postaci czterech zachodnich państw) bez Japonii, która rozwiązywała wszystkie ważniejsze problemy pokoju wersalskiego na własnych 145 posiedzeniach; korespondencja amerykańskich emisariuszy do Rosji z Departamentem Stanu; dokumenty Komitetu Spraw Zagranicznych Senatu USA dowodzą, że Stany Zjednoczone i Wielka Brytania (w osobie Lloyda George'a) były prawie gotowe, by omawiać $\mathrm{z}$ bolszewikami warunki uznania ich władzy na zajętych przez nich terytoriach. Ale taki wariant wymagał skomplikowanych decyzji w odniesieniu do innych części Rosji, znajdujących się pod kontrolą białych czy samoustanowionych miejscowych władz.

Anglicy pojawili się w państwach bałtyckich w grudniu 1918 roku po wycofaniu się stamtąd wojsk kajzerowskich (chociaż pokój w Compiègne pozostawiał tam Niemców) nie po to, by odbudować niepotrzebny już front wschodni, ale by utworzyć kontrolowany przez nich kordon sanitarny (,przeciw bolszewizmowi”) od Bałtyku po Morze Czarne. Zdobycze Piotra I nie dawały spokoju Wielkiej Brytanii przez dwa stulecia i w związku z tym nie mogła nie wykorzystać sytuacji i pokoju brzeskiego. Do tego celu potrzebne były niezależne państwa bałtyckie.

Reżimy powstałe jeszcze przy poparciu niemieckich wojsk szybko przeorientowały się na Anglię. W sierpniu 1919 roku angielski emisariusz powołał północno- 
-zachodni rząd przy generale Nikołaju Judeniczu i, jak pisze Manuił Margulies, osobiście uczestniczył w sporządzeniu listy tego rządu, posługując się słabym rosyjskim zażądał od wszystkich jego członków, by podpisali „uznanie estońskiej niezależności, w przeciwnym razie Ententa zaprzestanie pomocy". Pomoc i tak nie została udzielona nawet podczas inwazji Judenicza, a „niezależny” estoński rząd w odpowiedzi na prośbę o pomoc odpowiedział, że „byłoby niewybaczalną głupotą ze strony narodu estońskiego, jeśliby on to uczynił" ${ }^{37}$.

Wielka Brytania w praktyce uznała Łotwę i kierowała jej sprawami z samoustanowionymi władzami. Rolę łotewskiego przedstawiciela w Londynie spełniał Brytyjczyk G. Simpson, który przekazał ambasadorowi USA „Protest w imieniu rządu tymczasowego Łotwy w związku z tym, że wojska niemieckie niezgodnie z artykułem XII pokoju, podyktowanego przez marszałka Focha 11 września 1918 r. opuszczają Łotwę nie otrzymawszy rozkazu od państw sojuszniczych" - podkreślał, że - „Wojska niemieckie są nastrojone przeciwko władzy miejscowej” i ,pozostawiają wszelką broń, umundurowanie i umocnienia wojskom bolszewickim" ${ }^{38}$. Sojuszniczka Rosji Wielka Brytania w ten sposób dokonała wysiłku, by po kapitulacji Niemiec (wspólnego przeciwnika Rosji i Wielkiej Brytanii) uwolnione od niemieckiej kapitulacji rosyjskie terytoria nie wróciły do Rosji, a były od niej odłączone. Dla Wielkiej Brytanii byli tak samo niewygodni biali jak czerwoni, ponieważ pod różnymi flagami mogli zjednoczyć rozpadające się państwo.

S.D. Sazonow, reprezentujący Denikina, spotkawszy się w Paryżu z jawną niechęcią wysłuchania na konferencji przedstawicieli zjednoczonej Rosji i pomocy im, nieustannie donosił pełnomocnikom, że państwa zachodnie nie będą pomagały Rosji. „Cała generalicja, nie tylko Denikina, ale także Wrangla, liczyła na to, że sojusznicy w odpowiedzi na lojalność, która przekraczała granice zdrowego rozsądku, nie tylko powinni, ale rzeczywiście pomogą Armii Ochotniczej - wspomina „łącznik” G. Michajłowski, - nie wierzyć w to oni nie chcieli, licząc, że Sazonow [...] nie chce przedstawić sojusznikom poważnych argumentów"39.

Na próżno ostatni ambasador Rosji w Waszyngtonie Boris Bachmietjew skierował do Departamentu Stanu spis warunków pokojowego załatwienia „rosyjskiego problemu" na konferencji paryskiej, wśród których znajdowały się:

${ }^{37}$ М.В. Назаров, Тайна России. Историософия ХХ века, Москва, Русский вестник, 1999, ss. $69-70$.

${ }^{38}$ Ambassador of the USA in Britain (Davis) - to acting Secretary of State, London, 20 Dec. 1918. Foreign Relations of the United States, 1919, The Paris Peace Conference, vol. II. Wash. D.C., The GPO, s. 479.

${ }^{39}$ Г.Н. Михайловский, Записки. Из истории российского внешнеполитического ведомства. 1914-1920. В двух книгах, Книга 2. Октябрь 1917 - ноябрь 1920, Москва, Международные отношения, 1993, s. 207. 
„bezwzględne anulowanie umowy brzeskiej i innych porozumień zawartych przez Niemcy po 7 listopada 1917 roku z władzami działającymi w imieniu Rosji lub politycznymi i narodowymi ugrupowaniami pretendującymi do władz w dowolnej części terytorium byłego Imperium Rosyjskiego”; „Wyprowadzenie wojsk niemieckich z terytorium byłego Imperium Rosyjskiego”; „Restytucja wszystkich sądów, [...] zapasów złota, stopów, obligacji i papierów wartościowych, przekazanych im (Niemcom) przez działającą władzę po 7 listopada 1917 roku"40.

Ententa jednak nie uznała ani jednego emigracyjnego rządu Rosji reprezentowanego przez białych. Denikin z rozżaleniem odnotował, że w dodatku sojusznicy, zwłaszcza Wielka Brytania, chętnie i pospiesznie uznawały nowe państwa, powstałe na obrzeżach Rosji. Francja jednak uznała de facto rząd Wrangla odpłaciwszy mu za uratowanie Piłsudskiego i Polski - ostoi francuskich wpływów na wschodzie Europy. Zrobiono to niebezinteresownie, a w celu udzielenia Wranglowi prawnego mandatu na rozporządzanie przedrewolucyjnymi rosyjskimi aktywami za granicą i opłacenia zakupu broni u ententy. Ale kiedy bolszewicy zawarli radziecko-polską umowę i przerzucili wojska na południe, to ani Polacy, ani Francuzi nie pomogli białemu Krymowi. Józef Piłsudski cynicznie ogłosił, że żadnego sensu w pomocy Wranglowi nie widzi: „Niech Rosja jeszcze pognije 50 lat pod władzą bolszewików, a my wstaniemy na nogi i okrzepniemy"41.

Wszystko to potwierdzają emigracyjne archiwa i książki białych ${ }^{42}$, w tym bardzo ciekawe notatki Gieorgija Nikołajewicza Michajłowskiego ${ }^{43}$, który żył i pracował w przedwojennej Pradze i Bratysławie, gdzie był aresztowany, a później przepadł w obozach NKWD. Notatki zarekwirowane w 1945 roku przez Armię Czerwoną i przechowane w moskiewskich archiwach jeszcze przez pół wieku do czasu publikacji są cenne z tego powodu, że nie zostały zredagowane przez autora na podstawie późniejszych uogólnień.

${ }^{40}$ Acting Secretary of State - to Committee to negotiate peace. Dec. 13, 1918. Foreign Relations of the United States, 1919, The Paris Peace Conference, vol. II. Wash. D.C., The GPO, 1942, s. 477.

${ }^{41}$ Cytat za: Ю. Мацкевич, Победа провокации, Лондон, Канада: Заря, 1983, ss. 91-94.

${ }^{42}$ С. Мельгунов, Трагедия адмирала Колчака, Белград, Русская Типография, 1930; М. Маргулиес, Год интервенции, Берлин, изд-во З.И. Гржебина, 1923; А.И. Деникин, Мировые события и русский вопрос, Париж, Издательство Союза добровольцев, 1939.

${ }^{43}$ Gieorgij Nikołajewicz Michajłowskij - syn pisarza N.G. Garina-Michajłowskiego - chrześniaka imperatora Mikołaja I. W wieku 24 lat dzięki talentowi i encyklopedycznemu wykształceniu został naczelnikiem prawnej sekcji Ministerstwa Spraw Zagranicznych Rosji z prawem referowania ministrowi. Pozostawił notatki o niezwykłej wartości informacyjnej na temat pierwszych dni funkcjonowania MSZ po przewrocie październikowym, opisał wizytę Trockiego, który żądał, by ujawnić wszystkie tajne dokumenty i reakcję na to pracowników od kierownictwa do stenografistek. Jego syn dożył do roku 2006 w biedzie na Słowacji, wspomagany przez ambasadę Rosji, która zorganizowała jego spotkanie $\mathrm{z}$ autorką tego artykułu. 
„Komplikacje z Anglikami powstawały na gruncie niewątpliwej dwulicowości ich polityki - pisze Michajłowski - Jeśli jedną ręką oni podtrzymywali na południu Rosji Denikina a na Syberii Kołczaka, to druga - jawnych wrogów Denikina i w ogólności Rosji. Podobnie do tego jak wybrzeża Morza Bałtyckiego i nasze nadbałtyckie rubieże, u Wielkiej Brytanii pomoc znajdowały [...] brzegi Morza Czarnego i Kaspijskiego, taką samą pomoc otrzymywały ludy Kaukazu dążące do odłączenia. To charakterystyczny ton angielskiej polityki, który expressis verbis został określony przez samego Lloyda George'a w Parlamencie Angielskim, kiedy wprost powiedział, że wątpi w korzyści dla Anglii wynikające z odtworzenia uprzedniej potężnej Rosji”44.

Ogólne nastawienie w stosunku do Rosji na konferencji wersalskiej zbudowane było na niewiedzy, kontrowersjach, wahaniach, w oparciu o rozeznanie w sytuacji wewnętrznej i planowane wybory we własnych państwach, ciążącego poczucia obowiązku, żeby podjąć decyzję, ale także oczywistej chęci, by wykorzystać sytuację i zaplanować pokój bez Rosji (,„Rosja - ból głowy”).

Koncepcja amerykańska, jeszcze spotykająca się (prócz idei samostanowienia narodów i postulatu odżegnania się od wszelkich kolonii) z pewną aprobatą Lloyda George'a, spowodowała niezrozumienie i sprzeciw przede wszystkim Francji - zrujnowanej, która utraciła około 170 tysięcy mieszkańców oraz poniosła ogromne starty na swoim terytorium, będąc teatrem działań wojennych. Francja reprezentowała tradycyjną pozycję ukierunkowaną na zabezpieczenie narodowych potrzeb, otrzymanie maksymalnych reparacji, odzyskanie Alzacji i Lotaryngii, węgla z Zagłębia Saary, na maksymalne ograniczenie pokonanego nieprzyjaciela. Zderzenie tradycyjnego narodowego i nowego kosmopolitycznego światopoglądu znajduje doskonałe odbicie w interpretacji pokoju wersalskiego widocznym w Archiwum putkownika House 'a ${ }^{45}$ i w pamiętnikach znakomitego Andre Tardieu, który grał podobną rolę we francuskiej delegacji na paryskiej konferencji pokojowej jak Edward House w amerykańskiej ${ }^{46}$.

Andre Tardieu zostanie potem premierem, podczas jego kadencji zostanie zawarty paktBrianda-Kellogga (zudziałem wszędobylskiego J. Shotwella). Clemenceau i Tardieu kategorycznie sprzeciwiali się zaproszeniu bolszewików na konferencję i wszelkim kontaktom z nimi. Clemenceau kategorycznie twierdził, że z prawnego punktu widzenia, podpisując pokój brzeski, Rosja zdradziła obowiązki sojusznicze i skazała Francję na łaskę Niemców. Niemcy otrzymały ziemie i surowce oraz mogły przerzucić setki tysięcy żołnierzy na front zachodni. Dla Clemenceau leninowski pokój brzeski zwalniał sojuszników od wszelkich zobowiązań, włączając także obietnicę wolnego dostępu przez czarnomorskie cieśniny do Morza Śródziemnego.

\footnotetext{
${ }^{44}$ Г.Н. Михайловский, Записки..., ор.cit., s. 209.

45 Архив полковника Хауса, Москва 1939, http://militera.lib.ru/db/house_em01/index.html [dostęp: 20.07.2020].

${ }^{46}$ А. Тардье, Мир, Госполитиздат, Москва, 1943.
} 
Zaczynający jako lewicowy polityk, ale rozczarowany w stosunku do lewicowej ideologii francuski premier uważał Lenina i bolszewików za rosyjskich ,gilotynistów”, którzy unicestwili, podobnie jak jakobini, wszystko co szlachetne w imię rewolucji. Margaret MacMillan przytacza zapis rozmowy lorda Balfoura z Clemenceau, podczas której ten ostatni wyraził obawę, że zaproszenie bolszewików zachęci radykalne elementy we Francji do wystapień ulicznych, co wywoła strach klasy średniej, doprowadzi do wystapień rewolucyjnych w Europie i stworzy niekorzystne tło dla konferencji wersalskiej ${ }^{47}$. Chociaż Francji potrzebna była Rosja, która zwróciłaby jej carskie długi, Clemenceau nie nalegał na prawdziwą interwencję i wojskową operację przeciwko bolszewikom - ich zwolennikiem był tylko marszałek Foch.

Tak więc Clemenceau wolał „odbudowaną zjednoczoną białą Rosję”, dochodzi do wniosku Margaret MacMillan: „Wielka Brytania, raczej osłabioną czerwoną Rosję. Curzon, z jego niechęcią do wszystkiego za czym optowali bolszewicy, jednocześnie był zachwycony, że Rosjanie utracili kontrolę nad Kaukazem" - uprzedzał, że - „Wielka Brytania powinna uważnie obserwować, żeby Denikin - lider białych na południu nie zawładnął znowu tym terytorium"48.

Sazonow wiedział o „poważnym planie Anglii mającym na celu parcelację Rosji. Państwa bałtyckie powinny były ostatecznie odciąć Rosję od Morza Bałtyckiego, Kaukaz być buforem niezależnym od Rosji, między nią, Turcją i Persją, podobnym niezależnym państwem miał zostać Turkiestan, żeby raz na zawsze przegrodzić drogę do Indii. Persja miała dostać się całkowicie we władanie Anglii a „niezależność" Kaukazu, Turkiestanu i państw bałtyckich miała być ograniczona w praktyce do protektoratu Anglii nad tymi terytoriami”"49. Takie rozważania w brytyjskim parlamencie i prasie nie były rzadkością, co pozwoliło wysunąć bolszewickiej propagandzie (a potem radzieckiej historiografii) tezę o istnieniu „planu ententy” zniszczenia Rosji, wykorzystywana ona była nie bez sukcesu w rekrutacji do Armii Czerwonej w celu obrony „socjalistycznej Ojczyzny” od obcych zaborców.

Żadnego rządowego planu na papierze w postaci programu działania oczywiście nie było. Białym nie tylko USA, ale także Wielka Brytania nie zamierzały pomagać, mimo zapewnień Churchilla. A w murach parlamentu brytyjskiego otwarcie mówiono o rozpadzie Imperium Rosyjskiego. Brytyjskie wojska w ramach „,interwencji” w Rosji nie przedsiębrały realnych działań wojennych przeciw Armii Czerwonej, odpierając od czasu do czasu mało znaczące ataki czerwonych. Jednak samo wprowadzenie obcych wojsk niewątpliwie pomagało bolszewikom w propagandzie.

Jeśli chodzi o cel ostateczny, to brytyjskie zadania nie były zgodne z wilsonowskim programem „Czternastu punktów” - nade wszystko z koncepcją samostano-

\footnotetext{
${ }^{47}$ M. Mac Millan, Paris $1919 \ldots$, op.cit., s. 69.

${ }^{48}$ Ibidem, s. 74.

${ }^{49}$ Г.Н. Михайловский, Записки..., ор.cit., s. 209.
} 
wienia narodów, godząc w istnienie brytyjskich kolonii. Ale idea „uznania faktycznie istniejących rządów" 50 pozwalała Lloydowi George'owi znaleźć wspólny język z Wilsonem. Znalazło to swój przejaw w zgodzie na zwołanie konferencji na Wyspach Książęcych. Jednak sam Wilson, według wszelkich danych, nie wypowiadał się w Wersalu za rozpadem Rosji.

W styczniu 1919 roku Lloyd George i Wilson wystosowali zaproszenie do bolszewików, białych struktur a także wszystkich samoustanowionych rządów do udziału w konferencji na Wyspach Książęcych. Zaproponowano, by niezwłocznie rozpocząc rozmowy białych z bolszewikami, co niezwykle poruszyło białych, natomiast bolszewicy rozważali przyjęcie zaproszenia. Bullitt w swoim sprawozdaniu dla amerykańskiego Senatu przedstawił dokument na temat zadania amerykańskiego dyplomaty Williama Bucklera, który przeprowadził w Sztokholmie intensywne rozmowy z Maksymem M. Litwinowem, z udziałem brytyjskiego posła w Szwecji. Litwinow faktycznie był nieoficjalnym ambasadorem bolszewików nie tylko w Londynie, ale także na konferencji wersalskiej. Posiedzenia Rady Dziesięciu niejednokrotnie rozpoczynały się lekturą telegramów od Litwinowa, nie zaś od Bachmietiewa.

Litwinow robił „liczne propozycje i projekty”, które Buckler przekazywał telegraficznie do Paryża delegacji USA i które były przez prezydenta Wilsona uznane za na tyle ważne, że ten przedstawił je w całości Radzie Dziesięciu. Wszystkie te dokumenty na stu stronach zostały opublikowane w suplemencie do dokumentów Senackiego Komitetu Spraw Zagranicznych Kongresu USA w związku z rozpatrzeniem ratyfikacji umowy wersalskiej.

Dalej w sprawozdaniu Bullitta mowa jest o tym, że „Spotkanie Backlera z Litwinowem było tym wydarzeniem, które przechyliło decyzję podjętą podczas posiedzenia na korzyść konferencji na Wyspach Książęcych, którą przedstawił Lloyd George. [...] Lloyd George zaproponował, by zaprosić do Paryża przedstawicieli różnych rosyjskich rządów”. Porównał nawet planowane forum ze „zwołaniem w Imperium Rzymskim namiestników odległych prowincji dla złożenia sprawozdań" ${ }^{1}$. Przy czym, jak o tym świadczą dokumenty i literatura, przedstawiciele Łotwy i Estonii, nie bez konsultacji z Anglią, zgodzili się przybyć, uzależniając to od uznania ich suwerenności ze strony wielkich mocarstw i ograniczając swój udział do rozmów o pokoju z Rosją radziecką; Gruzja oświadczyła, że nie przyjedzie, ponieważ mowa będzie o Rosji, a „Gruzja to nie Rosja” ${ }^{52}$.

${ }^{50}$ The Intimate Papers of Colonel House, London 1928, vol. IV, ss. 202-204.

${ }^{51}$ Bullit Exhibit $N$ 11. Treaty of Peace with Germany. Hearings before the Committee of foreign relations. United States Senate, $66^{\text {th }}$ Congress, First session, Washington D.C., 1919, ss. 1235, 1236.

${ }^{52}$ Zob. The Bullitt Mission to Russia. Foreign Relations of the USA, Russia 1919, Washington D.C., 1942; Lloyd George. The Truth about Peace Treaties; The Intimate Papers of Colonel House, London 1928; У. Черчилль, Мировой кризис, Гос. военное изд-во, Москва 1932; Князь Г. Трубецкой, Годы смут и надежд 1917-1919 г., Монреаль, Братство преп. Иова Почаевского, 1981. 
W Paryżu prócz tego zorganizowano tzw. „Rosyjskie posiedzenie polityczne” składające się z przedstawicieli białych liderów - Aleksandra Kołczaka, Antona Denikina, Nikołaja Czajkowskiego i Nikołaja Judenicza. Na ręce sekretarza konferencji wersalskiej przyszła nota podpisana przez Sazonowa i Czajkowskiego w imieniu ,zjednoczonych rządów” Syberii, Archangielska i Południowej Rosji, w której podkreślano, że nie może być mowy o wymianie poglądów z bolszewikami. Wówczas zostało wystosowane memorandum W. Bullitta do pułkownika House'a z 30 stycznia 1919 r. zawierające pilną rekomendację, by terminowo i jednoznacznie ,informować rząd Archangielska, że zaprzestaniemy zaopatrywać go w broń, jeśli on nie przyjmie propozycji sojuszników"53.

Znamienne było wystapienie Wilsona z 14 lutego 1919 roku przed Radą Dziesięciu, w którym prezydent wypowiedział sekretne słowa: „Wojska sojusznicze nie robią niczego dobrego w Rosji, więcej, one pomagają reakcji” (tzn. białym N.N.). Wilson bardziej otwarcie wyraził zamiar nawiązania stosunków z bolszewikami, kiedy „inne rosyjskie rządy nie chcą spotkać się z sojusznikami na Wyspach Książęcych" ${ }^{54}$. To, że USA od początku były w kontakcie z bolszewikami, szczególnie na Syberii i na Dalekim Wschodzie zostało potwierdzone świadectwami i niektórymi badaniami rosyjskimi, które wykazały na podstawie dokumentów podwójną działalność Stanów Zjednoczonych ${ }^{55}$.

Podróż Bullitta do Rosji odbyła się w lutym i marcu 1919 roku, zaraz po tym jak projekt konferencji na Wyspach Książęcych zaczął zawodzić i USA zaczęły realizować własne inicjatywy. W memorandum amerykańskiego członka rosyjskiej sekcji Komisji Pokojowej w związku z kontrowersjami odnośnie do krajów bałtyckich i stosunkiem do białych rządów wyciagnięto odkrywczy wniosek, że amerykański „cel w odniesieniu do Rosji nie jest zgodny z celami innych zainteresowanych rządów, a porozumienie na temat ekonomicznej i wojskowej ingerencji nie zostało jeszcze osiagnięte" 56 .

Jednocześnie House skierował inteligentnego i wykształconego w Europie Shotwella do Sazonowa. „Urząd” Sazonowa działał jako „ministerstwo spraw zagranicznych” Sił Zbrojnych Południa Denikina - „rządu”, który pośród białych miał reputację najbardziej reakcyjnego i którego podchmieleni oficerowie podobno śpiewali Boże chroń cara. Shotwell przedstawił się Sazonowowi jako „osobisty przedstawiciel prezydenta Wilsona", nie wtajemniczając w swój status oficjalnego eksperta

${ }^{53}$ Bullit Exhibit N 12. Treaty of Peace with Germany. Hearings before the Committee of foreign relations. United States Senate, $66^{\text {th }}$ Congress, First session, Washington D.C., 1919, s. 1239.

${ }^{54}$ Foreign Relations of the USA. 1919, vol. III, Washington D.C. 1943, ss. 1041-1044.

${ }_{55}^{5}$ М. Светачев, США и Россия. 1917 год: пролог к интервенции, „Вестник Центра по изучению международных отношений в Тихоокеанском регионе” 2, 2001, s. 116.

${ }^{56}$ Ibidem, s. 475. 
amerykańskiej delegacji grupy Inquiry. Obiecał on Sazonowowi zorganizować wizytę białych w Waszyngtonie, by mogli przedstawić swoje poglądy na przyszłość Rosji Departamentowi Stanu. Jednocześnie ,osobisty przyjaciel” Wilsona delikatnie i taktycznie, ale stanowczo radził Sazonowowi ukrywać przed amerykańskimi partnerami monarchistyczne nastroje, jeśli takie istnieją, i przekonywał go o przychylności Wilsona dla zachowania jedności Rosji.

Wizyta „denikinowskich dyplomatów” w USA, w której przygotowaniu uczestniczył także Gieorgij Michajłowski nie odbyła się ${ }^{57}$. W końcu 1950 roku „zaangażowanie” w obronę jedności Rosji przekształciło się w walkę o wolność „zniewolonych" przez Rosję narodów. Początkowo rezolucja Kongresu USA, a potem artykuł P.L.86-90 z 1959 roku wyznaczyły cel wyzwolenia ,ofiary imperialistycznej polityki komunistycznej Rosji" ${ }^{58}$, nazywając nimi wszystkie narody związkowych republik oprócz rosyjskiego, a nawet „Kozację i Idel-Ural”. Stany Zjednoczone wówczas dopiero zaczynając kierowanie światową polityką i nie mając, jak państwa europejskie tradycyjnych instrumentów, wolały nie stwarzać niewygodnych dla siebie sfer konfliktów w walce o strefy wpływów w postaci rozpadu ZSRR. W 1949 roku na temat ,problemu rosyjskiego" na konferencji paryskiej została opublikowana monografia, w której autor Borys Jefimowicz Sztejn, współpracownik Narodowego Komisariatu Spraw Wewnętrznych, przygotowywał dla potrzeb służbowych analityczne notatki, był też zaznajomiony z dokumentami, faktami i okolicznościami wydarzeń. Szczególnie pragmatyczny ton jego tajnych notatek, dziś dostępnych w Archiwum Polityki Zagranicznej RF, uderzająco odróżnia się od zarozumiałego stylu jego książki charakterystycznego dla tej epoki. Jednak fakty i zacytowane dokumenty prowadzą do tego samego wniosku, co świadectwa białej emigracji: głównym celem, nade wszystko Wielkiej Brytanii, było wykorzystanie sytuacji porewolucyjnej w Rosji dla oderwania od niej obszarów strategicznych. Sztejn wyraża żal z powodu zerwania konferencji na Wyspach Książęcych, przyznając, że bolszewicy gotowi byli przystać na handel terytoriami i obwinia niektóre zachodnie państwa o zakulisowe machinacje, które doprowadziły do zakończenia obrad. Francja, pisze Sztejn, skierowała do białogwardyjskich rządów ,przyjacielską radę” by odmówiły uczestnictwa ${ }^{59}$. Rząd radziecki odpowiedział na to zgoda, stawiając warunki, spośród których głównym było wyprowadzenie wszystkich obcych wojsk z terytorium byłego Imperium Rosyjskiego za wyjątkiem Polski i Finlandii oraz tych ,zawartych w porozumieniu z rządami ententy lub korzystających z jej finansowej, wojskowej lub

\footnotetext{
${ }^{57}$ Г.Н. Михайловский, Записки ..., op.cit., s. 250.

${ }^{58}$ Congressional Record. Proceedings and debates of the $86^{\text {th }}$ Congress, vol. 105, P. 9, Washington 1959 , s. 11399.

${ }^{59}$ Б.Е. Штейн, Русский вопрос на Парижской мирной конференции, Москва, Госполитиздат, 1949, s. 102.
} 
innej pomocy" ${ }^{90}$. Na podstawie rezultatu rozmów w Moskwie z Bullittem i Bucklerem zostały wypracowane liczne dokumenty i stanowiska. Telegram Narodowego Komisariatu Spraw Wewnętrznych proponował koncesje na złoża kopalne, zasoby leśne i obiecywał rozpatrzyć problem dalszej aneksji terytoriów rosyjskich przez państwa ententy ${ }^{61}$. W związku z taką otwartością Lloyd George na posiedzeniu Rady Dziesięciu poświęconym niepowodzeniu konferencji na Wyspach Książęcych zaproponował nawet stanowczo odrzucić ,przypuszczenie, że takie cele były powodem interwencji w Rosji”' 62 .

Choć A. Etkind, nie będąc historykiem, prawdopodobnie z przekonaniem przedstawia informację o zgodzie bolszewików na propozycje W. Bullitta jako własne odkrycie i nikomu wcześniej nieznany fakt, to: „Projekt pokojowej propozycji Sojuszniczych i Zjednoczonych Państw opracowany przez przedstawiciela rządu USA Bullitta i rządu RFSRR" zostal opublikowany w ZSRR w 1958 r. ${ }^{63} \mathrm{~W}$ nim rzeczywiście zawarta byla pozycja mówiąca o tym, że w sytuacji wojny domowej sankcjonowano podział Rosji pod warunkiem, że narody mają prawo do zmiany władzy:

„Wszystkie istniejące faktycznie rządy w Rosji i Finlandii zachowują władzę na należących do nich terytoriach za wyjątkiem sytuacji przewidzianej podczas konferencji, kiedy mieszkające na zarządzanym de facto terytorium narody same zechcą zmienić władzę" ${ }^{64}$.

Ten projekt zawierał także punkt o natychmiastowym zaprzestaniu „wszelkiego zbrojnego wsparcia antyradzieckich rządów”, ponieważ w Radzieckiej Rosji sądzono, że wszelkie białe struktury podtrzymywane są wyłącznie z zewnątrz. W konsekwencji w literaturze radzieckiej pomijano te szczegóły i fakty, które świadczyły o gotowości akceptacji podziału Rosji, a podkreślano głównie to, że „radzieckie propozycje pokojowe" zostały odrzucone.

Możliwe, że włączone do projektu przez Moskwę uwagi budziły wątpliwości wobec sugestii Lenina, który faktycznie mógł zapomnieć o swoich obietnicach, jak zamierzał postapić ze „sprośnym”, zgodnie z jego barwnym stylem, pokojem brzeskim. Wahające się i niemogące osiaggnąc porozumienia delegacje ententy na dodatek wolały poczekać na wyniki obiecującej początkowo ofensywy admirała Kołczaka. Jednak ententa żadnego konkretnego poparcia białym nie zaproponowała, co pozwoliło Margaret MacMillan wnioskować:

${ }^{60}$ Внешняя политика СССР. Сборник документов, Издательство Высшей партийной школы, Москва 1944, t. 1, ss. 227-229.

${ }^{61}$ Foreign Relations of the USA, Russia, 1919, Washington D.C., 1942, s. 39.

${ }^{62}$ Foreign Relations of the USA, 1919, vol. V, Washington D.C., 1943, s. 14.

63 Документы внешней политики СССР, t. 2, Москва 1958, ss. 91-95.

${ }^{64}$ Ibidem, s. ???. 
„Choć bolszewikom udało się potem stworzyć propagandowy wizerunek światowego kapitalizmu, który z całą mocą uzbroił się przeciwko ich rewolucji, to w rzeczywistości sojusznicy nie bardzo pomagali białym w uniknięciu klęski”" ${ }^{\circ 5}$.

Wiosną 1919 roku ententa rozpoczęła drugi etap ,interwencji”, która odzwierciedlała nie klasowe i ideologiczne motywacje państw zachodnich, a ich cele geopolityczne i wojskowo-strategiczne, co wyjaśnia naprzemienną współpracę z Czerwoną i Białą Armią. Przykładem jest poparcie Amerykanów udzielone czerwonym partyzantom przeciwko Kołczakowi, który nie odpowiadał Stanom Zjednoczonym. Ten z kolei prosił ententę o usunięcie amerykańskich emisariuszy, którzy mogli mieć wpływ na pogorszenie jego relacji z Waszyngtonem ${ }^{66}$. Natomiast 6 maja 1919 roku Clemenceau, Wilson i Lloyd George zażądali od Kołczaka, by uznał wszystkie nowo utworzone na terytorium Rosji państwa ${ }^{67}$.

Anglicy pojawili się na Kaukazie i Zakaukaziu do listopada 1919 roku, zajęli Baku i linię kolejową do Batumi. Minister spraw zagranicznych Arthur Balfour wystosował znamienne oświadczenie, opublikowane przez brytyjską gazetę „The Guardian” we wrześniu 2004 roku w związku z wydarzeniami wokół Gruzji i tragedią w Biesłanie:

„Jedyne, co interesuje mnie na Kaukazie, to kto kontroluje drogę, którą pompowana jest ropa z Baku do Batumi, a aborygeni mogą porozrywać się nawzajem na kawałki, jest mi to obojętne" ${ }^{\prime 68}$.

Przy zachęcie Anglików, Gruzini zajęli wrogą pozycję w stosunku do Rosjan w ogólności, a Armii Ochotniczej w szczególności. Kiedy naiwny przedstawiciel wojskowej misji brytyjskiej, generał George Rawlinson, zwrócił się z wezwaniem do narodów Kaukazu, by podporządkowały się Zbrojnym Siłom Południa i powiedział, że sprzeciw generałowi Denikinowi będzie przyjęty jako akt niechęci w stosunku do sojuszników, rząd brytyjski, postępując zgodnie z wskazaniami lorda Curzona publicznie go zdezawuował, publikując „list głównego komisarza Anglii na Kaukazie Wardropa do „ministra spraw zagranicznych” Gegeczgori, w którym była mowa o tym, że poglądy Rawlinsona zupełnie nie odzwierciedlają poglądów rządu brytyjskiego [...], a Gegeczgori na zjeździe gwardii ludowej stwierdził wprost: „Nie leży w interesach Anglii włączenie Zakaukazu w granice Rosji”69.

\footnotetext{
${ }^{65}$ M. MacMillan, Paris 1919..., op.cit., s. 73.

${ }^{66}$ C. Мельгунов, Трагедия адмирала Колчака, cz. III, t. 1, Berlin, Русская типография, 1931, ss. 113-114.

${ }^{67}$ C. Мельгунов, Трагедия адмирала Колчака, cz. I, Berlin, Русская типография, 1930, ss. 51-53.

68 John Laughland in Batumi, Georgia on their mind, [w:] https://www.theguardian.com/ world/2004/apr/01/georgia.oil [dostęp: 25.08.2020].

${ }^{69}$ А. Деникин, Очерки русской смутыл. Вооруженные силь юга России, t. 5, Berlin 1925, s. 127.
} 
Los misji Bullitta podczas konferencji wersalskiej okazał się negatywny. Wilson, zmęczony kastrowaniem swojej koncepcji podczas uzgadniania paktu o Lidze Narodów, zachowaniem kolonii pod flagą „terytoria mandatowe”, nieprzezwyciężonym pragnieniem Francji i Wielkiej Brytanii „ukarać przykładnie” Niemcy według pogańskiej zasady „biada pokonanym”, nie przyjął Bullitta. Margaret MacMillan, marginalnie wspomniawszy o jego misji, charakteryzuje pogłoski na temat entuzjastycznego z niej raportu jako naiwną wiarę niedoświadczonych młodych ludzi, pozostających pod złudnym wpływem Lenina i bolszewickich dyplomatów, dla których amerykańscy przedstawiciele byli tylko „pożytecznymi idiotami" ${ }^{\text {"70 }}$. Jednak jej publikacja świadczy raczej o tym, że kompletne dane o misji Bullitta nigdy nie zostały ujawnione w archiwach USA.

Literatura nie dostarcza wiedzy na temat dalszych kontaktów Bullitta z Litwinowem, którego osoba i działalność dla badaczy pozostaje tajemnica. Ani w teczce osobistej „Litwinow” w Archiwum Polityki Zagranicznej RF, ani w innych teczkach nie ma nawet śladu informacji o jego rozmowach z Bullittem (w Rosji), następujących po nich rozmowach w Sztokholmie i wysłaniu not i telegramów na adres Rady Dziesięciu. W krajowych publikacjach można przeczytać niemało o tym, jak za rządów Stalina Litwinowa stopniowo marginalizowano, o wzajemnej nienawiści między nim a Gieorgijem Cziczerinem, o pikantnych szczegółach, jakoby donosili na siebie nawzajem, o rzekomo przygotowywanym zamachu Ławrentija Berii na Litwinowa, ale nie ma niczego o jego roli w sekretnej dyplomacji 1919 roku. Niemniej jednak, sądząc z danych pośrednich, Litwinow kontynuował swą tajną misję w stosunkach z USA zarówno przed, jak i po oficjalnym uznaniu ZSRR przez Waszyngton. W 1929 roku znajdował się w delegacji pięciu wysoko postawionych radzieckich urzędników z sekretną wizytą w USA, gdzie wystąpił z wykładem na temat strategicznych planów Rosji radzieckiej przed wybranym amerykańskim audytorium na zamkniętym posiedzeniu zorganizowanym przez Radę Stosunków Międzynarodowych. (U źródeł RSM była grupa ekspertów Inquiry, która brała udział w konferencji wersalskiej. A w 1921 roku dyrektorem RSM był członek Inquiry Isaiah Bowman dobrze znający misję Bullitta i jego kontakty z Litwinowem). Według relacji dyrektora wykonawczego Rady do Spraw Stosunków Międzynarodowych Waltera Mallory'ego Litwinow i towarzyszący mu bolszewicy formułowali swoje odpowiedzi tak, ,że zadowalały audytorium składające się z amerykańskich bankierów, ale mogły dyskredytować tych ludzi w kraju"71.

\footnotetext{
${ }^{70}$ M. MacMillan, Paris $1919 \ldots$, op.cit.

${ }^{71}$ Cуt. za: В.А. Алексеев, “Третий Рим” или Гарвардская школа, Москва, Обозреватель,
} 1994. s. 29. 
Jednak grupa związana z USA utrzymywała się w radzieckim kierownictwie partyjnym długo, nawet wówczas, kiedy Stalin rozczarował się kierunkiem amerykańskim w polityce i przestał dowierzać Litwinowowi co, jak jest współcześnie interpretowane, groziło niebezpieczeństwem dla jego życia. Ponieważ w tamtych latach pozbycie się niewygodnego człowieka pod byle pozorem nie było trudne, pozostawienie Litwinowa na najwyższych stanowiskach, nawet ze stopniowym odsuwaniem go od podejmowania ważnych decyzji w polityce zagranicznej, świadczy o tajnym znaczeniu tej postaci, którego na razie nie udaje się rozszyfrować.

Pośrednie i ostrożne wpływy proamerykańskiej grupy były odczuwalne aż do początków lat 40., o czym świadczą notatki i rekomendacje wychodzące z kancelarii Litwinowa, gdzie analizowano politykę zagraniczną USA ewidentnie przemilczając ważniejsze dokumenty i fakty, które stanowiły klucz do rozumienia istoty tych wpływów. To sprzyjało utwierdzeniu się wczesnej radzieckiej historiografii w stereotypie wyróżniającym pozytywnie „młodą demokratyczną Amerykę” pośród „starych imperialistycznych drapieżników", co po części było jeszcze dziełem Michaiła Pokrowskiego $^{72}$.

Sam Litwinow w notatce analitycznej z maja 1945 roku ocenił politykę USA wobec Rosji w ciagu XX wieku całkiem pozytywnie. Podkreślił w szczególności, że Stany Zjednoczone dłużej niż inne państwa nie uznawały nowych porządków na terytorium historycznej Rosji, starały się wierzyć w notę Colby’ego, w której wyjaśniano nieuznanie przez Waszyngton nowych państw, w tym władzy radzieckiej, „uczuciem przyjaźni i poczuciem obowiązku w stosunku do wielkiego narodu, który w potrzebie odniósł się przyjaźnie do USA" i tym, że Amerykanie jakoby nie chcieli przyczynić się do „rozwiązania rosyjskiego problemu wyłącznie poprzez rozpad Rosji" 73 .

Jednak już w 1925 roku Charles Seymour wydał Osobiste notatki pułkownika House'a w czterech tomach, a wkrótce Ludowy Komisariat Spraw Wewnętrznych ZSRR opublikował niewielkim nakładem rosyjski przekład rozdziałów odnoszących się do Rosji, co ujawniło prawdziwy sens „ogólno-demokratycznych zasad” Wilsona. Litwinow nie mógł o tym nie wiedzieć, tym bardziej że właśnie z nim w Sztokholmie rozmowy prowadziła Komisja przygotowująca pokój wersalski. Tam również rozmawiali z nim Bullitt i oficjalny dyplomata USA Buckler na temat konferencji na Wyspach Książęcych i porozumienia się w sprawie wyprowadzenia z Archangielska dziecięciotysięcznego kontyngentu wojskowego ententy. Litwinow zagwarantował

${ }^{72}$ Вудро Вильсон. Мировая Война. Версальский мир. По документам изапискам председателя американского комитета печати на Версальской конференции Стэннарта Бекера, предисловие М. Павлович, Москва - Петроград, Государственное издательство, 1923.

${ }^{73} \mathrm{Na}$ temat noty Colby'ego zob. Колби нота, [w:] http://biblioclub.ru/index.php?page=dict\&ter $\min =868044$ [dostęp: 10.10 .2020$]$. 
wówczas, że wchodząc do Archangielska bolszewicy pozwolą sojusznikom spokojnie się wycofać i „nie będą prześladować tych Rosjan, którzy z sojusznikami współpracowali”, o czym Buckler powiadomił Wilsona ${ }^{74}$.

Aleksandr Parvus, który otworzył biuro w Londynie, także kontaktował się z Litwinowem. Właśnie Litwinow był zorientowany w tym, że anglosaska część ententy nie zamierzała popierać ani Denikina, ani Kołczaka, ani żadnego białego rządu, który byłby w stanie zjednoczyć państwo. Lloyd George na posiedzeniu Rady Dziesięciu w obecności Clemenceau, Orlanda i Sonina, proponujący prowadzić rozmowy z wybranym jednym rządem białych, nalegał, żeby wszystkie struktury białych uznać za „niereprezentatywne”, a w odniesieniu do Kołczaka nawet ostrzegał, że ten zbiera wokół siebie przedstawicieli starego reżimu i prawdopodobnie jest w głębi duszy monarchistą. Litwinow był tym przedstawicielem bolszewików, za pośrednictwem którego przekazywane było Moskwie stanowisko Rady Dziesięciu, w tym warunek zaproszenia bolszewików na Wyspy Książęce oraz natychmiastowe wyprowadzenie wojsk z Polski i Litwy. Nie tylko Lloyd George, ale i Wilson zaniepokojony „bezpośrednim niebezpieczeństwem zniweczenia wszelkiej nadziei na pozyskanie terenów nadbałtyckich”, żądał ,jednoznacznie dać do zrozumienia, że bolszewicy powinni całkowicie opuścić Litwę i Polskę"75.

Zainteresowanie budzi artykuł - prawie oda na cześć Litwinowa - napisany w 1996 roku przez profesora Uniwersytetu Kentucky Hugh Phillipsa i opublikowany w postaci osobnej zszywki przez Instytut Kennana przy Międzynarodowym Centrum Naukowym Wilsona ${ }^{76}$. Litwinow przedstawiony został jako jedyny działacz bolszewicki i dyplomata szczerze zachwycony Ameryką i prezydentem Rooseveltem. Rzekomo był on wolny od marksistowsko-leninowskiego dogmatyzmu, a jego długoletnia praca na kluczowych stanowiskach przy ,jego przeciwieństwie Stalinie” wydaje się zagadką, która zajmuje nie tylko autora. Litwinow, według oceny Phillipsa, nie posiadał poglądów, które byłyby rozbieżne $\mathrm{z}$ amerykańskimi, za wyjątkiem jednego grzechu - Litwinow podzielał brak zaufania i niechęć swojego totalitarnego bossa do Polski.

Z artykułu wynika, że dokumenty przekazywane do Wersalu w 1919 roku były przygotowywane przez Litwinowa, a Bullitt służył raczej jako kurier przekazujący tajne dokumenty. Autor szczególnie akcentuje rolę Litwinowa w rozmowach, które

${ }^{74}$ Bullit Exhibit N11. Hearings before the Committee of foreign relations. United States Senate. $66^{\text {th }}$ Congress, First session, Washington D.C., 1919, s. 1238.

75 Запись У. Буллита беседы в кабинете М. Пишона на Кэ д’Орсэ. Hearings before the Committee of foreign relations. United States Senate. $66^{\text {th }}$ Congress, First session, Washington D.C., 1919, ss. 1236-1238.

${ }^{76}$ M. Maxim, Litvinov and Soviet-American Relations, 1918-1946 by Hugh Phillips, [w:] https://www.wilsoncenter.org/sites/default/files/op263_maxim_litvinov_phillips_1996.pdf [dostęp: 20.07.2020]. 
prowadzone były wówczas za pośrednictwem amerykańskiego dyplomaty Bucklera w ramach kontaktów bezpośrednich z prezydentem Wilsonem i Lloydem George'em na konferencji wersalskiej.

Właśnie Litwinow samowolnie napisał list do Wilsona jeszcze w grudniu 1918 roku, w celu załagodzenia sytuacji związanej z ostrą repliką ludowego komisarza Cziczerina na amerykańską koncepcję i program „Czternastu punktów”. W liście do amerykańskiego prezydenta i brytyjskiego premiera podkreślał zbieżność podejścia Wilsona do kwestii europejskich z propozycjami radzieckimi, a także straszył tym, że przedłużenie interwencji ententy doprowadzi do restauracji monarchii w Rosji. Powołując się na archiwum Bucklera na Uniwersytecie Yale, Phillips przytacza, że Litwinow obiecywał nie tylko pójście na kompromis w akceptacji długu rządu carskiego (jakoby spornej kwestii we wszystkich rozmowach na temat uznania ZSRR), ale też gwarantował nietykalność amerykańskich firm i przyznanie im dodatkowych koncesji. W zamian za to Litwinow prosił o duże pieniądze na zakup techniki. (W 1921 roku Litwinow kierował przekazaniem USA ogromnych sum w obcej walucie jako zapłatę za maszyny, technikę, ziarno i produkty medyczne. Jak wiadomo, środki te zostały pozyskane ze sprzedaży za bezcen skarbów Ermitażu i innych dzieł sztuki, o czym świadczą napisy pod eksponatami w amerykańskich muzeach).

„Demokratyczna Ameryka” rzeczywiście okazała się bardzo tolerancyjna w stosunku do bolszewików, William Bullitt był w ogóle nimi oczarowany, a referat na temat bolszewickiego terroru przybyłych z Rosji ambasadorów Włoch i Francji amerykańska delegacja na konferencji wersalskiej nazwała grubą przesada.

Jednocześnie USA zapewniały białych o niezmienności amerykańskiej postawy, o bezwzględnej konieczności zachowania ziem nadbałtyckich jako części Rosji, w tym przez Shotwella - na etapie, kiedy głównym graczem nad Bałtykiem była Wielka Brytania i jej wojska. Stany Zjednoczone rzeczywiście później od wszystkich uznały niezależność republik bałtyckich i ratyfikacji towarzyszyło potwierdzenie negatywnego stosunku do rozpadu Rosji. Pozycja zmieniła się o 180 stopni po przekształceniu ZSRR w równoważną światową potęgę w rezultacie zwycięstwa w 1945 roku.

Za wilsonowską filozofią nowego świata i za selektywnością jej wdrożenia ukrywała się ambicja amerykańskiej realpolitik. Stany Zjednoczone z przyczyn oczywistych rozważały na ile pożyteczny dla nich może okazać się rozpad Imperium Rosyjskiego: mienszewicka Gruzja miała podpisaną w Poti umowę z kajzerowskimi Niemcami, litewska Taryba (rząd) w Kownie, utworzony w grudniu 1917 roku przez niemieckie wojska okupacyjne, ogłosiła wieczną i nienaruszalną przyjaźń także z Niemcami, a następnie szybko przeorientowała się na Wielką Brytanię. Ukraina prawie cała okupowana była przez wojska niemieckie. Reorientacja ukraińskich elit na anglosaską część ententy w danym momencie oznaczała poszerzenie nie amery- 
kańskich, a brytyjskich wpływów i pokusę Wielkiej Brytanii, by kontynuować tradycyjną politykę koalicji. Lecz później, kiedy Wielka Brytania w 1940 roku uznała za praworządne przywrócenie przedrewolucyjnego terytorium Rosji i powrót państw bałtyckich w granice Rosji radzieckiej, USA konsekwentnie nie uznawały przywrócenia władzy ZSRR nad tymi terytoriami.

Na konferencji wersalskiej nie obawiano się reżimu bolszewickiego, lecz odrodzenia w nowym kształcie geopolitycznego giganta. Ścigano się we współzawodnictwie o kontrolę nad strategicznymi terenami bałtyckimi. Pełen sens, znaczenie i treść misji Bullitta, zawarty w różnych częściach jego sprawozdania rządowi amerykańskiemu trzeba jeszcze studiować i systematyzować, podobnie jak działalność grupy Inquiry i „pułkownika” House’a. Takich badań poświęconych konkretnie „rosyjskiemu problemowi" na paryskiej konferencji pokojowej jest mało na Zachodzie, gdzie w najlepszym przypadku poświęca się temu zagadnieniu jeden rozdział lub kilka stronic, jak zauważono w przedmowie do unikatowej monografii J.M. Thompsona ${ }^{77}$.

W rocznicę stulecia rewolucji rosyjskiej, wojny domowej i I wojny światowej dalsze badania tego problemu, także w odniesieniu do sprawy polskiej, są pożądane. Trzeba wziąć pod uwagę plany i projekty zarówno zwycięzców, jak i samych polskich działaczy, często ogarniętych ideą rewanżu na Rosji. Należy wprowadzić do obiegu naukowego utajnione lub zapomniane dokumenty dla lepszego zrozumienia polityki światowej, układu wokół Rosji nie tylko z perspektywy minionego wieku, lat poprzedzających II wojnę światową, ale także współcześnie, gdy odżywają konflikty zakorzenione w przeszłości.

Ttumaczenie

Hanna Kowalska-Stus

\section{Literatura}

Алексеев В.А., “Третий Рим” или Гарвардская школа, Москва, Обозреватель, 1994.

Архив полковника Хауса, Москва 1939, http://militera.lib.ru/db/house_em01/index. html [dostęp: 20.07.2020].

Внешняя политика СССР. Сборник документов, t. 1, Издательство Высшей партийной школы, Москва 1944.

Вудро Вильсон. Мировая Война. Версальский мир. По документам и запискам председателя американского комитета печати на Версальской кон-

\footnotetext{
${ }^{77}$ J..M. Thompson, Russia, Bolshevism, and the Versailles Peace, op.cit.
} 
ференции Стэннарта Бекера, предисловие М. Павлович, Москва Петроград, Государственное издательство, 1923.

Деникин А., Очерки русской смуты. Вооруженные силы юга России, t. 5, Berlin 1925.

Деникин А.И., Мировые события и русский вопрос, Париж, Издательство Союза добровольцев, 1939.

Документы внешней политики СССР, t. 2. Москва 1958.

Запись У. Буллита беседы в кабинете М. Пишона на Кэ д 'Орсэ. Hearings before the Committee of foreign relations. United States Senate. $66^{\text {th }}$ Congress, First session, Washington D.C., 1919.

Киссинджер Г., Дипломатия, Москва, Ладомир, 1994, 1996.

Колби нота, [w:] http://biblioclub.ru/index.php?page=dict\&termin=868044 [dostęp: 10.10.2010].

Листиков С.В., Мир без России: представительство Белого движения на Парижской конференции, „Вестник МГИМО” nr 1(4), 2009.

Маргулиес М., Год интервениии, Берлин, изд-во З.И. Гржебина, 1923.

Мацкевич Ю., Победа провокаиии, Лондон, Канада: Заря, 1983.

Мельгунов С., Трагедия адмирала Колчака, cz. I, Berlin, Русская типография, 1930.

Мельгунов С., Трагедия адмирала Колчака, cz. III, t. 1, Berlin, Русская типография, 1931.

Мельгунов С., Трагедия адмирала Колчака, Белград, Русская Типография, 1930.

Михайловский Г.Н., Записки. Из истории российского внешнеполитического ведомства. 1914-1920. В двух книгах, Книга 2. Октябрь 1917 - ноябрь 1920, Москва, Международные отношения, 1993.

Назаров М.В., Тайна России. Историософия ХХ века, Москва, Русский вестник, 1999.

Нарочницкая Н., Русская революиия и мир в XX столетии: через призму «русского вопроса» на Парижской мирной конферениии, „Перспективы. Электронный журнал”, 4(12), 2017 (октябрь-декабрь), ss. 7-36.

Плешко А.О., Роль У. Черчилля в решении «Русского вопроса» на Парижской мирной конференции», „Вестник Челябинского государственного университета" 1915.

Сазонов С.Д., Воспоминания. Репринтное воспроизведение издания 1927 года, Париж - Москва, Международные отношения, 1991.

Светачев М., США и Россия. 1917 год: пролог к интервенции, „Вестник Центра по изучению международных отношений в Тихоокеанском регионе” 2 , 2001. 
Стоун Н., Первая мировая война: Краткая история, пер. с англ. И.В. Лобанова, Москва 2010.

Тардье А., Мир, Госполитиздат, Москва 1943.

Тойнби А.Дж., Цивилизащия перед судом истории. Сборник, пер. И.Е. Киселевой,

М.Ф. Носовой, Москва, Прогресс-Культура, Ювента, 1996.

Трубецкой Г., Годы смут и надежд 1917-1919 г., Монреаль, Братство преп. Иова Почаевского, 1981.

Уткин А.И., Первая мировая война, Москва, Алгоритм, 2001.

Фрейд 3., Буллит У., Томас Вудро Вильсон. 28-й президент США Психологическое исследование, Москва, Прогресс, 1992.

Черчилль У., Мировой кризис, Москва, Гос. военное изд-во, 1937.

Шевенман Ж-П., Европа выходит из истории?, Москва, АСТ, 2015.

Штейн Б.Е., Русский вопрос на Парижской мирной конференции, Москва, Госполитиздат, 1949.

Эткинд А., Мир мог быть другим. Уильям Буллит в попытках изменить XX век, Москва, Время, 2015.

Acting Secretary of State - to Committee to Negotiate Peace. Dec. 13, 1918. Foreign Relations of the United States, 1919, The Paris Peace Conference, vol. II. Wash. D.C., The GPO, 1942.

Ambassador of the USA in Britain (Davis) - to acting Secretary of State, London, 20

Dec. 1918. Foreign Relations of the United States, 1919, The Paris Peace Conference, vol. II. Wash. D.C., The GPO.

Brownell W., Billings R., So Close to Greatness: The Biography of William C. Bullitt, New York, Macmillan, 1988.

Bullit Exhibit N 11. Treaty of Peace with Germany. Hearings Before the Committee of Foreign Relations. United States Senate, 66 ${ }^{\text {th }}$ Congress, First Session, Washington D.C., 1919.

Bullit Exhibit N 12. Treaty of Peace with Germany. Hearings Before the Committee of Foreign Relations. United States Senate, $66^{\text {th }}$ Congress, First Session, Washington D.C., 1919, s. 1239.

Bullit Exhibit N11. Hearings Before the Committee of Foreign Relations. United States Senate. $66^{\text {th }}$ Congress, First Session, Washington D.C., 1919.

Casella-Blackburn M., The Donkey, the Carrot, and the Club: William C. Bullitt and Soviet-American Relations, 1917-1948, Praeger, Westport, Conn 2004.

Churchill W., The World Crisis. 1916-1918, t. 1, New York, Charles Scribner's Sons, 1927.

Churchill W.S., His Complete Speeches, 1897-1963, vol. 2, ed. R.R. Games, New York, Chelsea House Publishers; R.R. Bowker Company, 1974.

Congressional Record. Proceedings and Debates of the $86^{\text {th }}$ Congress, vol. 105, P. 9 , Washington 1959, s. 11399. 
Farnsworth B., William C. Bullitt and the Soviet Union, Bloomington, Indiana University Press, 1967.

Foreign Relations of the USA, Russia, 1919, Washington D.C., 1942.

Foreign Relations of the USA, 1919, vol. III, Washington D.C., 1943.

Foreign Relations of the USA, 1919, vol. V, Washington D.C., 1943.

Howden A.D., Mr. House of Texas, New York - London, Funk \& Wagnalls, 1940.

John Laughland in Batumi, Georgia on Their Mind, [w:] https://www.theguardian. com/world/2004/apr/01/georgia.oil [dostęp: 25.08.2020].

Josephson H., James T. Shotwell and the Rise of Internationalism in America, Madison, NJ: Fairleigh Dickinson University Press, 1974.

Lloyd George. The Truth About Peace Treaties; The Intimate Papers of Colonel House, London 1928.

MacMillan M., Paris 1919. Six Months That Changed the World, New York, Random House Trade Paperbacks 2012.

Maxim M., Litvinov and Soviet-American Relations, 1918-1946 by Hugh Phillips, [w:] https://www.wilsoncenter.org/sites/default/files/op263_maxim_litvinov_ phillips_1996.pdf [dostęp: 20.07.2020].

Memorandum by A.W. Dulles. 30 December 1918. Foreign Relations of the United States, 1919. The Paris Peace Conference, vol. II. Washington D.C., The GPO. Memorandum by Lieutenant A.A. Berle, Jr., December 10, 1918. Foreign Relations of the United States, 1919. The Paris Peace Conference, vol. II, Washington, GPO, 1942.

Renouvin P., Les origines immédiates de la guerre, 28 juin-4 aoüt 1914, Paris, A. Costes, 1925.

Seton-Watson R.W., Britain and the Dictators, Cambridge, The Macmillan Company, 1938.

Seymour Ch. (ed.), The Intimate Papers of Colonel House, London, Ernest Benn, 1928, vol. IV, ss. 202-204.

Shotwell J.T., At the Paris Peace Conference, Appendix VII. The Organization of the American Delegation, Macmillan Company, New York 1937.

The Bullitt Mission to Russia. Foreign Relations of the USA, Russia 1919, Washington D.C., 1942.

The Intimate Papers of Colonel House, vol. IV, London 1928.

Thompson J.M., Russia, Bolshevism and the Versailles Peace, Princeton, Princeton University Press, 2015.

Treaty of Peace with Germany. Hearings Before the Committee of Foreign Relations. United States Senate. $66^{\text {th }}$ Congress, First Session, Washington D.C., The GPO, 1919.

Tuveson E.L., Redeemer Nation. The Idea of America's Millennial Role, Chicago, University of Chicago Press, 1980. 


\section{References}

Alekseev V.A., "Tretij Rim" ili Garvardskaja shkola ["Third Rome" or Harvard School] Moskva, Obozrevatel', 1994.

Archiv polkovnika House'a [Colonel House's Archives], Moskva 1939, http://militera.lib.ru/db/house_em01/index.html [accessed: 20.07.2020].

Cherchill' U., Mirovoj krizis [World Crisis] Moskva, 1937.

Denikin A., Ocherki russkoj smuty. Vooruzhennye sily juga Rossii [Essays on Russian

Troubles. Armed Forces of the South of Russia], vol. 5, Berlin 1925.

Denikin A.I., Mirovye sobytija i russkij vopros [World Events and the Russian Question], Parizh, Izdatel'stvo Sojuza dobrovol'cev, 1939.

Dokumenty vneshnej politiki SSSR [USSR Foreign Policy Documents], vol. 2. Moskva 1958.

Frejd Z., Bullit U., Tomas Vudro Vil'son. 28-j prezident SShA Psihologicheskoe issledovanie [Thomas Woodrow Wilson. $28^{\text {th }}$ U.S. President Psychological Research], Moskva, Progress, 1992.

Jetkind A., Mir mog byt'drugim. Uil'jam Bullit v popytkah izmenit' HH vek [The

World Could Be Different. William Bullitt in an Attempt to Change the Twentieth Century], Moskva, Vremja, 2015.

Kissindzher G., Diplomatija, [Diplomacy] Moskva, Ladomip, 1994, 1996.

Kolbi nota, [in:] http://biblioclub.ru/index.php?page=dict\&termin=868044 [accessed: 10.10.2010].

Listikov S.V., Mir bez Rossii: predstavitel'stvo Belogo dvizhenija na Parizhskoj konferencii [A World Without Russia: Representation of the White Movement at the Paris Conference], „Vestnik MGIMO” nr 1(4), 2009.

Margulies M., God intervencii [Year of Intervention], Berlin, izd-vo Z.I. Grzhebina, 1923.

Mackevich Ju., Pobeda provokacii [The Victory of Provocation], London, Kanada: Zarja, 1983.

Mel'gunov C., Tragedija admirala Kolchaka, [The Tragedy of Admiral Kolchak], p. I, Berlin, Russkaja tipografija, 1930.

Mel'gunov C., Tragedija admirala Kolchaka, [The Tragedy of Admiral Kolchak], p. III, vol. 1, Berlin, Russkaja tipografija, 1931.

Mel'gunov S., Tragedija admirala Kolchaka [The Tragedy of Admiral Kolchak], Belgrad, Russkaja Tipografija, 1930.

Mihajlovskij G.N., Zapiski. Iz istorii rossijskogo vneshnepoliticheskogo vedomstva. 1914-1920. V dvuh knigah, Kniga 2. Oktjabr'1917-nojabr'1920 [Notes. From the History of the Russian Foreign Policy Department. 1914-1920. In Two 
Books, Book 2. October 1917 - November 1920] Moskva, Mezhdunarodnye otnoshenija, 1993.

Narochnickaja N., Russkaja revoljucija i mir v HH stoletii: cherez prizmu «russkogo voprosa» na Parizhskoj mirnoj konferencii [The Russian Revolution and the World in the Twentieth Century: Through the Prism of the "Russian Question" at the Paris Peace Conference], "Perspektivy. Jelektronnyj zhurnal”, 4(12), 2017 (oktjabr'-dekabr'), ss. 7-36.

Nazarov M.V., Tajna Rossii. Istoriosofija HH veka [The Secret of Russia. Historiosophy of the Twentieth Century] Moskva, Russkij vestnik, 1999.

Pleshko A.O., Rol' U. Cherchillja v reshenii «Russkogo voprosa» na Parizhskoj mirnoj konferencii» [The Role of W. Churchill in Solving the "Russian Question" at the Paris Peace Conference], ,Vestnik Cheljabinskogo gosudarstvennogo universiteta" 1915.

Sazonov S.D., Vospominanija. Reprintnoe vosproizvedenie izdanija 1927 goda [Memories. Reprint Reproduction of the 1927 Edition], Parizh-Moskva, Mezhdunarodnye otnoshenija, 1991.

Shevenman Zh-P., Evropa vyhodit iz istorii? [Is Europe Out of History?], Moskva, ACT, 2015.

Svetachev M., SShA i Rossija. 1917 god: prolog $k$ intervencii [USA and Russia. 1917: Prologue to the Intervention], "Vestnik Centra po izucheniju mezhdunarodnyh otnoshenij v Tihookeanskom regione" 2, 2001.

Shtejn B.E., Russkij vopros na Parizhskoj mirnoj konferencii [Russian Question at the Paris Peace Conference], Moskva, Gospolitizdat, 1949.

Stoun N., Pervaja mirovaja vojna: Kratkaja istorija [World War I: A Brief History], trans. I.V. Lobanova, Moskva 2010.

Tard'e A., Mir [World] Moskva, Gospolitizdat, 1943.

Tojnbi A.Dzh., Civilizacija pered sudom istorii [Civilization Before the Judgment of

History] Sbornik, trans. I.E. Kiselevoj, M.F. Nosovoj, Moskva, ProgressKul'tura, Juventa, 1996.

Trubeckoj G., Gody smut i nadezhd 1917-1919 g. [The Years of Troubles and Hopes 1917-1919], Monreal', Bratstvo prep. Iova Pochaevskogo, 1981.

Utkin A.I., Pervaja mirovaja vojna [World War I], Moskva, Algoritm, 2001.

Vneshnjaja politika SSSR. Sbornik dokumentov [Foreign Policy of the USSR. Collection of Documents], vol. 1, Izdatel'stvo Vysshej partijnoj shkoly, Moskva 1944.

Vudro Vil'son. Mirovaja Vojna. Versal'skij mir. Po dokumentam i zapiskam predsedatelja amerikanskogo komiteta pechati na Versal'skoj konferencii Stjennarta Bekera [World War. The Peace of Versailles. According to Documents and Notes from the Chairman of the American Press Committee at the Versailles Conference, 
Stannart Becker], predislovie M. Pavlovich, Moskva - Petrograd, Gosudarstvennoe izdatel'stvo, 1923.

Zapis'U. Bullita besedy v kabinete M. Pishona na Kje d'Orsje [U. Bullitt's Recording of a Conversation in M. Pichon's Office on Ke d'Orsay], Hearings before the Committee of foreign relations. United States Senate. $66^{\text {th }}$ Congress, First session, Washington D.C., 1919. 